Cite this: Org. Chem. Front., 2014, 1 , 661

Received 25th April 2014, Accepted 20th May 2014 DOI: $10.1039 / c 4 q 000123 k$ rsc.li/frontiers-organic

\title{
Carbopalladation of bromoene-alkynylsilanes: mechanistic insights and synthesis of fused-ring bicyclic silanes and phenols $\uparrow$
}

\author{
Marie-Caroline A. Cordonnier, ${ }^{a}$ S. B. Jennifer Kan, ${ }^{b}$ Birgit Gockel, ${ }^{a}$ Shermin S. Goh ${ }^{a}$ \\ and Edward A. Anderson*a
}

The palladium-catalyzed cascade cyclization of silylated bromoenynes and alkenylstannanes provides a straightforward route to a range of bicyclic silylated cyclohexadienes. Mechanistic insights into aspects of carbopalladation and unusual palladium-mediated isomerizations have been obtained through the detection of reaction intermediates, the isolation of byproducts, and reaction monitoring by VT NMR spectroscopy. The utility of the bicyclic products is illustrated through oxidation to bicyclic enones and phenols.

\section{Introduction}

Phenols represent one of the most important aromatic functional groups, featuring in numerous natural products and drugs. ${ }^{1}$ Polycyclic phenols are of particular interest, as illustrated by highly bioactive compounds such as the anthracycline antibiotics, estrone, and morphine (Fig. 1). ${ }^{2}$ As traditional methods for phenol preparation require harsh conditions that may not be compatible with sensitive functional groups, ${ }^{3}$ phenols are usually incorporated at an early stage of a synthesis, thus restricting synthetic planning.

Late-stage phenolation is therefore an attractive prospect that has driven the development of transition metal-catalyzed aryl halide hydroxylation and aryl $\mathrm{C}-\mathrm{H}$ activation/oxidation methods. ${ }^{4}$ An alternative that avoids the prolonged heating often required by these processes is the use of a phenol surrogate, which could be revealed at a late stage of a synthetic route, but is stable to intermediate transformations. Here, arylboron derivatives have met with some success, particularly due to Molander's elegant work on the oxidation of aryl trifluoroborate salts, ${ }^{5}$ although the synthetic processability of these remains to be proven. In contrast, organosilanes - stalwarts of the protecting group field - display unrivalled tolerance towards multistep synthesis, and in recent work we have

${ }^{a}$ Chemistry Research Laboratory, University of Oxford, 12 Mansfield Road, Oxford, OX1 3TA, UK. E-mail: edward.anderson@chem.ox.ac.uk; Fax: +44 (0)1865 285002; Tel: +44 (0)1865 285000

${ }^{b}$ Department of Chemistry, University of Cambridge, Lensfield Road, Cambridge, CB2 1EW, UK

$\dagger$ Electronic supplementary information (ESI) available: Copies of ${ }^{1} \mathrm{H}$ and ${ }^{13} \mathrm{C}$ NMR spectra, and experimental details for NMR experiments. See DOI: $10.1039 / \mathrm{c} 4 \mathrm{qo} 00123 \mathrm{k}$
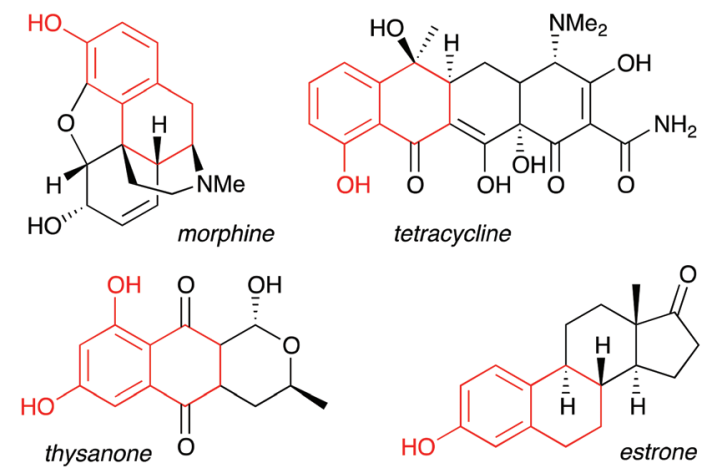

Fig. 1 Fused-ring phenols in bioactive natural products.

reported the use of arylsilanes as a source of phenols through Tamao-type oxidation. ${ }^{6,7}$

We have also disclosed a palladium-catalyzed cascade cyclization which prepares bi- or tricyclic products (1, Scheme 1) from the coupling of bromoenynes 2 with alkenyl- and dienylstannanes $3,{ }^{8}$ a reaction pioneered and impressively explored by Suffert et al. for the synthesis of various polycycles. ${ }^{9} \mathrm{~A}$ feature of this work is the requirement for an internal alkyne (i.e. $\mathrm{R}^{1} \neq \mathrm{H}$, Scheme 1 ) to avoid the formation of undesired triene isomers $\mathbf{4}$, which cannot undergo electrocyclization. One solution is to employ trimethylsilyl alkynes, ${ }^{10}$ and although this functionality indeed enables the desired cascade, it was clear that the resultant TMS-substituted cyclohexadienes would be of limited synthetic utility.

We realized that the use of a more functional silane would lead to a silicon-containing product capable of undergoing a range of further transformations, such as the aforementioned Tamao oxidation or Hiyama coupling. ${ }^{11}$ Indeed, we have illus- 
Previous work (Ref 8a):

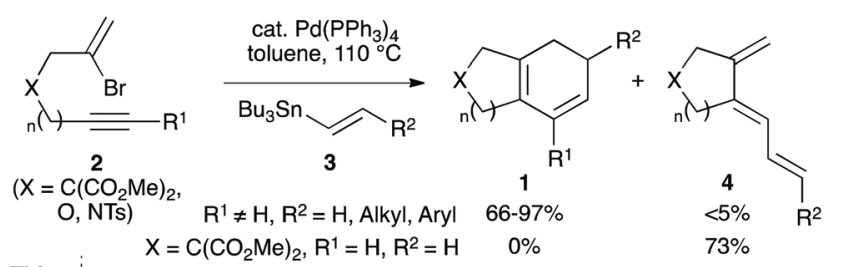

$\begin{array}{l:l}\text { This } & \mathrm{R}^{1}=\mathrm{SiR}_{2}^{3} \mathrm{O}-\mathrm{Pr}\end{array}$

$\checkmark$

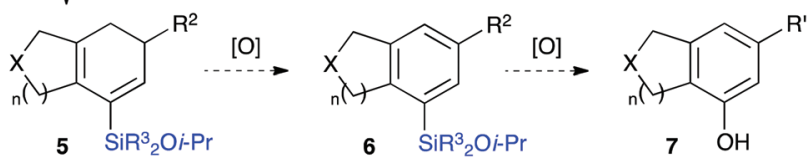

Scheme 1 Proposed synthesis of bicyclic phenols.

trated this principle in approaches to the CDE rings of rubriflordilactone $\mathrm{A}$, where arylsilanes formed from the cyclizations of bromoenynes could be oxidized to give specific tricyclic phenols. ${ }^{8 b, 12}$ In this paper we wish to report methods for the synthesis of a range of silylated bromoenynes, and their intermolecular coupling with alkenylstannanes to provide bicyclic silylcyclohexadienes 5. The oxidation of these dienes and silane substituents leads to bicyclic arylsilanes (6) and phenols (7) that would be challenging to prepare by other routes, and offers a de novo approach to ring systems of this type. ${ }^{13}$ Alongside this synthetic work, we expand on the mechanistic pathways operative in the cascade cyclization, including two unusual palladium-mediated isomerization processes. The unexpected observation of an unprecedented formal 4-endotrig cyclization to afford fused ring cyclobutenes is also described.

\section{Results and discussion}

\section{Synthesis of cascade cyclization substrates}

We selected a range of linkers to connect the bromoalkene and silylalkyne, such that bicyclic products containing 5 - to 7-membered rings, and heterocycles, could be obtained. Synthesis of carbon-tethered bromoenynes began with dimethylmalonate (Scheme 2), which following monoallylation with 2,3-dibromopropene (70\%) was alkylated with alkynyl electrophiles 8a-c to give bromoenynes 9a-c (69-90\%). The silylation of these alkynes was initially attempted using conditions employed in our arylsilane work. ${ }^{6 a}$ Thus, deprotonation of 9a with $n$-butyllithium followed by trapping of the resultant alkynyllithium species with the moisture-sensitive (diethylamino)chlorodimethylsilane $\left(\mathrm{Et}_{2} \mathrm{NMe}_{2} \mathrm{SiCl}\right)$ gave an intermediate aminosilane which was not isolated, but immediately converted to the dimethylisopropoxysilane 10a (Route A, Scheme 2) ${ }^{14}$ Perhaps unsurprisingly, this silane proved to be rather unstable towards chromatography, however through rapid chromatographic purification using a solvent system buffered with triethylamine, 10a could be isolated in $75 \%$ yield. In order to address the chromatographic instability of
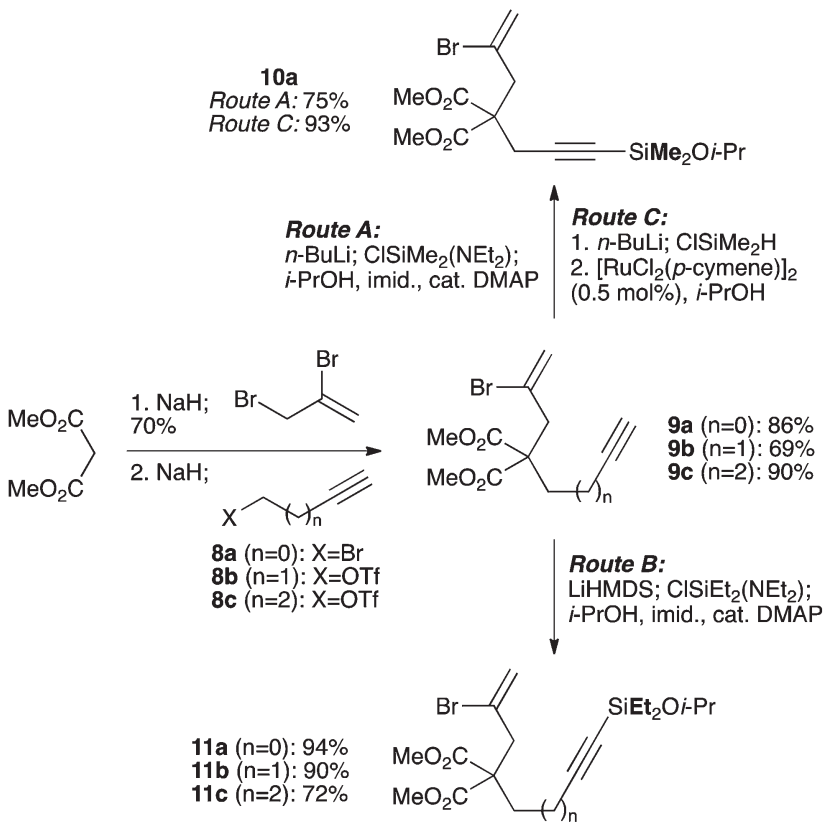

Scheme 2 Synthesis of malonate-derived silylbromoenynes.

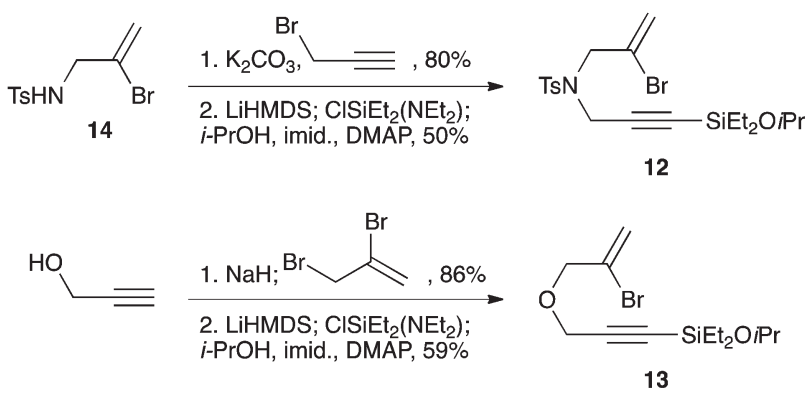

Scheme 3 Synthesis of heteroatom-tethered silylbromoenynes.

this dimethylisopropoxysilane, we employed the analogous diethylsilane reagent $\left(\mathrm{Et}_{2} \mathrm{~N}\right) \mathrm{SiEt}_{2} \mathrm{SiCl},{ }^{15}$ which gave the alkynyl isopropoxydiethylsilanes 11a-c in much improved yields following chromatographic purification (Route B). An alternative solution to the synthesis of 10a proved to be the use of dimethylchlorosilane $\left(\mathrm{HMe}_{2} \mathrm{SiCl}\right)$ as the acetylide trapping agent (Route C); the ensuing hydrolytically stable intermediate alkynylhydrosilane could be easily purified, and then smoothly oxidized to 10a using Lee and Chang's elegant rutheniumcatalyzed dehydrogenative silylation methodology ${ }^{16}$ which improved the yield of 10 a to $93 \%$.

The syntheses of heteroatom-tethered silylbromoenynes could be achieved uneventfully using equivalent chemistry, with sulfonamide-tethered enyne $\mathbf{1 2}$ and ether-linked enyne $\mathbf{1 3}$ being prepared in reasonable yields over two steps from known sulfonamide 14 and propargyl alcohol, respectively (Scheme 3).

\section{Cascade cyclizations of silylated bromoenynes}

With a selection of silylated alkynes in hand, their palladiumcatalyzed cascade cyclizations were examined. These reactions 
Table 1 Cascade cyclizations of silylated bromoenynes 10-13

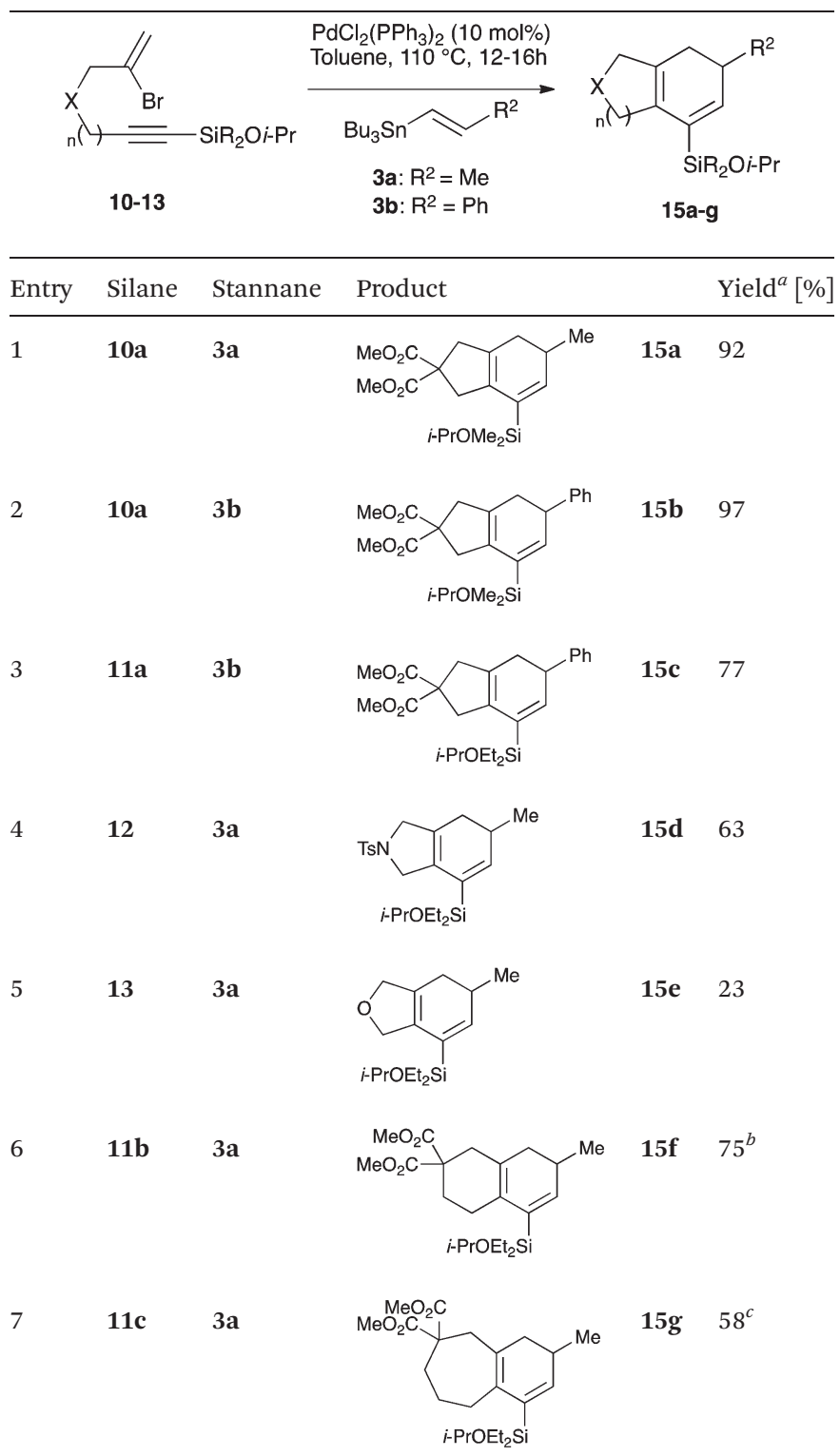

${ }^{a}$ Isolated yield. ${ }^{b}$ Isolated as an $80: 13: 7$ ratio of 15f:16a:17a.

${ }^{c}$ Isolated as a $63: 19: 18$ ratio of $\mathbf{1 5 g}: \mathbf{1 6 b}: \mathbf{1 7 b}$. See text for discussion.

were carried out according to our previously optimized conditions, ${ }^{8 a}$ using $\mathrm{PdCl}_{2}\left(\mathrm{PPh}_{3}\right)_{2}$ as precatalyst in refluxing toluene (Table 1). For the purposes of this work, the propenyl and styrenyl stannanes $\mathbf{3 a}$ and $\mathbf{3 b}$ were selected as generic cross-coupling partners. The reaction of dimethylsilane 10a was first investigated, which in spite of the relative instability of the alkynylsilane cyclized in excellent yields with both stannanes (92-97\%, entries 1, 2). Notably, the hydrolytic stability of the silane increases markedly upon cyclization owing to the increased steric bulk of the cyclohexadienyl substituent in 15a compared to the alkyne substituent of the starting material. The cyclizations of the (more robust) diethylsilane substrates proved more challenging (entries 3-5), with these reactions requiring longer reaction times, likely due to steric hindrance
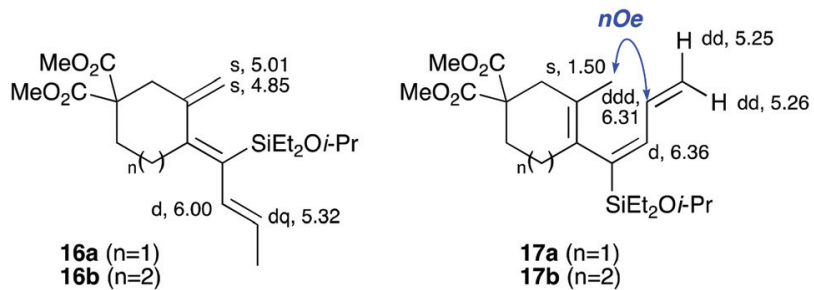

Fig. 2 Cyclization byproducts $16 \mathrm{a} / \mathrm{b}$ and $17 \mathrm{a} / \mathrm{b}$. Selected key ${ }^{1} \mathrm{H}$ NMR chemical shifts/multiplicities (in $\mathrm{CDCl}_{3}$ ) for 16a and 17a are shown.

of the key transmetallation step following carbopalladation. This resulted in lower isolated yields, as exemplified by the malonate and sulfonamide tethered enynes 11a and 12 which gave the corresponding bicycles 15c and 15d in 77 and 63\% yields respectively. The oxygen-tethered substrate $\mathbf{1 3}$ proved particularly troublesome, delivering the dihydrofuran product 15e in low yield, possibly due to instability of the allyl propargyl ether. Reaction of substrates featuring a longer tether also proved effective, giving the 6,6- and 7,6-bicyclic products $\mathbf{1 5 f}$ and $\mathbf{1 5} \mathbf{g}$ in good yields (entries 6, 7).

In the latter two cases, the desired bicyclic products were contaminated with significant quantities of partially separable isomeric byproducts 16a, b and 17a, b (Fig. 2), which were identified by careful analysis of ${ }^{1} \mathrm{H}-{ }^{1} \mathrm{H}$ COSY, and ${ }^{1} \mathrm{H}-{ }^{13} \mathrm{C}$ HSQC and HMBC 2D NMR spectra; ${ }^{17}$ the assignment of one of these sets of byproducts (16a and 17a) is discussed here. Byproduct 16a contains an exo-methylene unit $\left(\delta_{\mathrm{H}} 5.01\right.$ and $4.85 \mathrm{ppm})$, and two vicinal alkene protons $\left(\delta_{\mathrm{H}} 6.00 \mathrm{ppm}\right.$, dd, $J=15.5,1.5 \mathrm{~Hz}$; and $5.32 \mathrm{ppm}, \mathrm{dq}, J=15.5$ and $6.5 \mathrm{~Hz}$ ), the latter being characteristic of the trans-alkene of the propenyl unit. These data, together with key HMBC correlations, are strongly suggestive of the formal anti-carbopalladation/ cross-coupling product 16a, the formation of which is entirely consistent with our earlier results. ${ }^{8 a}$ The identification of the second byproduct proved less straightforward. Key signals in the ${ }^{1} \mathrm{H}$ NMR spectrum at $\delta_{\mathrm{H}} 6.36(\mathrm{~d}, J=10.6 \mathrm{~Hz}), 6.31(\mathrm{ddd}, J=$ 16.5, 10.6 and $9.7 \mathrm{~Hz}), 5.26(\mathrm{dd}, J=16.5$ and $2.0 \mathrm{~Hz})$ and $5.25 \mathrm{ppm}(\mathrm{dd}, J=9.8$ and $2.0 \mathrm{~Hz}$ ) revealed a connectivity between four alkene protons and thus the surprising presence of a 1,3-butadienyl unit. A further significant piece of evidence was the detection of a methyl singlet at $1.50 \mathrm{ppm}$, to which the proton at $6.33 \mathrm{ppm}$ showed an nOe enhancement. These combined observations, and ${ }^{1} \mathrm{H}-{ }^{13} \mathrm{C}$ correlations, led us to propose structure 17a, which features an $(E)$-alkenylsilane as part of a conjugated triene.

A mechanistic hypothesis for the formation of these byproducts is depicted in Scheme 4. The formation of byproduct 16 is consistent with our earlier observation ${ }^{8 a}$ that such undesired anti-trienes form in the course of the cyclization reaction, potentially via isomerization of the intermediate dienylpalladium complex 18 to its isomer $19 .{ }^{18}$ The rate of transmetallation of complex 19 is likely to exceed that of 18 , so even small amounts of 19 may lead to significant quantities of anti-triene 16 (i.e., a Curtin-Hammett situation). The formation of increased quantities of this triene for substrates $\mathbf{1 1 b}$ and $\mathbf{1 1 c}$ 

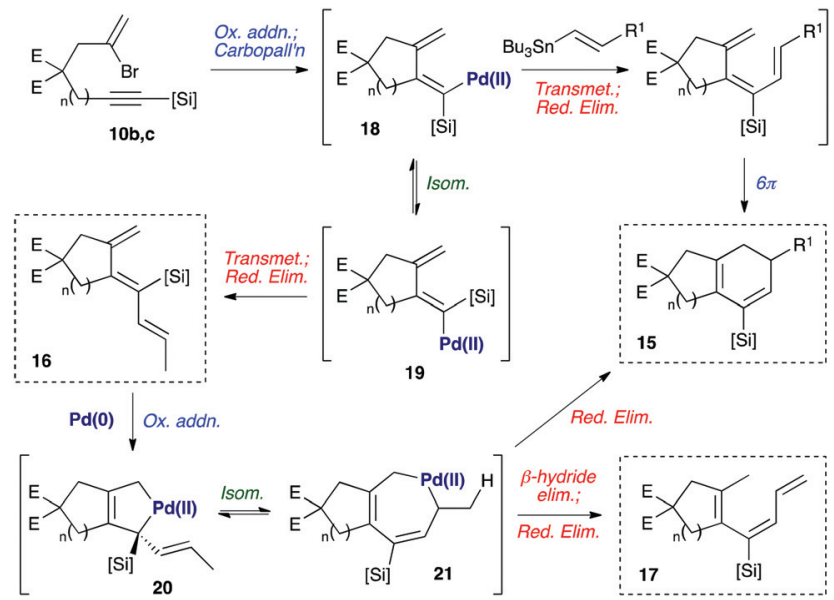

Scheme 4 Mechanistic proposal for byproduct formation. $\mathrm{E}=\mathrm{CO}_{2} \mathrm{Me}$, $[\mathrm{Si}]=\mathrm{SiEt}_{2} \mathrm{Oi}-\mathrm{Pr}$.

may reflect the increased flexibility of the larger tethering ring, which can distort to alleviate 1,3-allylic strain between the silyl substituent and exo-methylene in $\mathbf{1 9}$ - and therefore reduce the steric cost of placing a silane in this more hindered position. The formation of $\mathbf{1 7}$ may be explained by our second previous observation ${ }^{8 a}$ that anti-trienes can isomerize to bicyclic products on prolonged exposure to the reaction conditions. We suggest that this process may proceed via oxidative addition of $\operatorname{Pd}(0)$ with diene $\mathbf{1 6}$ to give a palladacyclopentene 20. ${ }^{19}$ This could undergo a 1,3-allylic migration of the palladium atom to the 7-membered palladacycle 21 , reductive elimination from which would afford the cyclohexadiene product $15{ }^{20}$ The formation of byproduct 17 could be rationalised by $\beta$-hydride elimination from this common palladacycle intermediate 21, followed by reductive elimination of the resultant palladium(II) hydride species. We presume that the steric hindrance imposed by the methyl group in $\mathbf{1 7}$ prevents a $6 \pi$-electrocyclization of this compound.

As $[4+1]$ oxidative additions of $\operatorname{Pd}(0)$ to dienes are rare, ${ }^{19}$ more concrete evidence to support these pathways was sought. Firstly, the formation of $\mathbf{1 6}$ via the intermediacy of dienylpalladium complex 19 was probed through the exposure of alkynylsilane 22 to one equivalent of $\mathrm{Pd}\left(\mathrm{PPh}_{3}\right)_{4}$ in $\mathrm{d}_{8}$-toluene at $110{ }^{\circ} \mathrm{C}$ (Fig. 3). The characteristic methylene signals of 22 at $\delta_{\mathrm{H}}$ 5.41 and $5.71 \mathrm{ppm}$ were rapidly converted $(10 \mathrm{~min})$ to two new sets of peaks: a prominent (apparent) singlet at $4.60 \mathrm{ppm}$, and two smaller singlets at 4.58 and $4.78 \mathrm{ppm}$. These were tentatively assigned as the exo-methylene peaks of the syn- and antidienylpalladium complexes $\mathbf{2 3}$ and $\mathbf{2 4}$ respectively, based on analysis by COSY and HSQC experiments. Support for this assignment was gained through the addition of 1.5 equivalents of tributylvinyltin to the NMR tube; further heating for 10 minutes led to exclusive formation of cyclohexadiene $\mathbf{2 5}$ and triene 26 in a ratio mirroring that of these intermediate species $(84: 16)$.

To explore the isomerization of 26 to 25 , a $1: 0.32$ mixture of these compounds, formed from reaction of silane 22 with

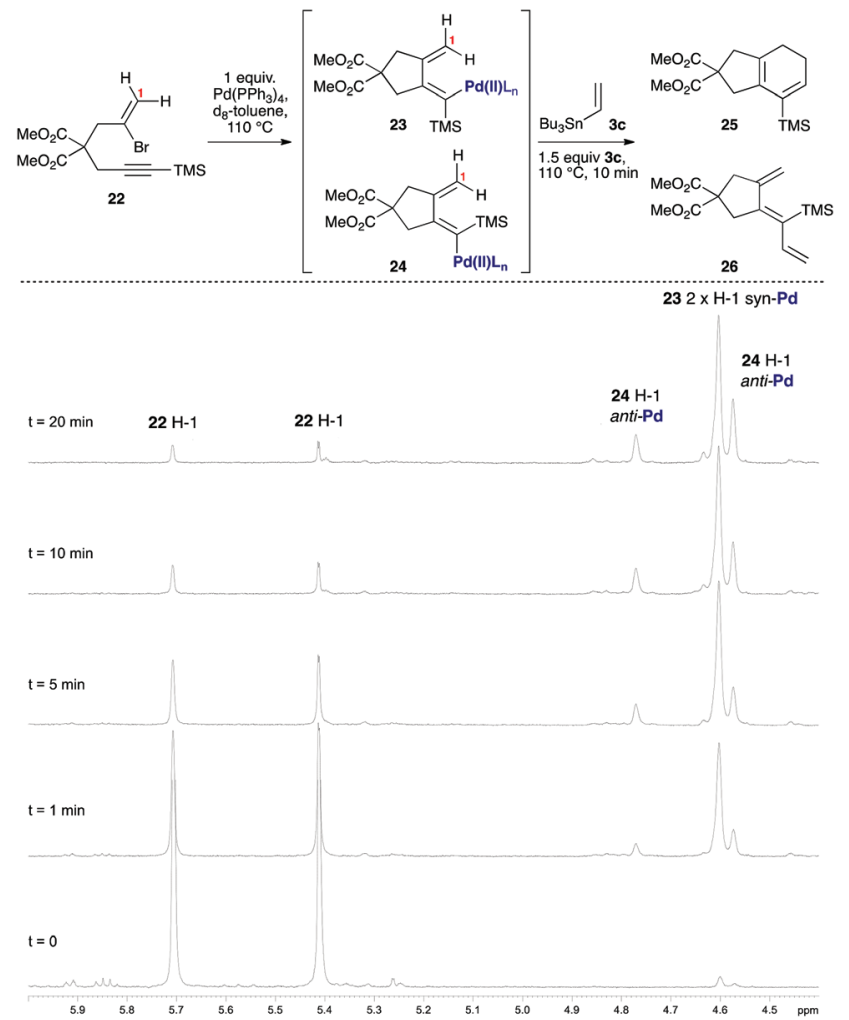

Fig. 3 Use of stoichiometric $\mathrm{Pd}\left(\mathrm{PPh}_{3}\right)_{4} / \mathrm{VT}^{1} \mathrm{H}$ NMR spectroscopy to probe the putative dienylpalladium(॥) intermediates.

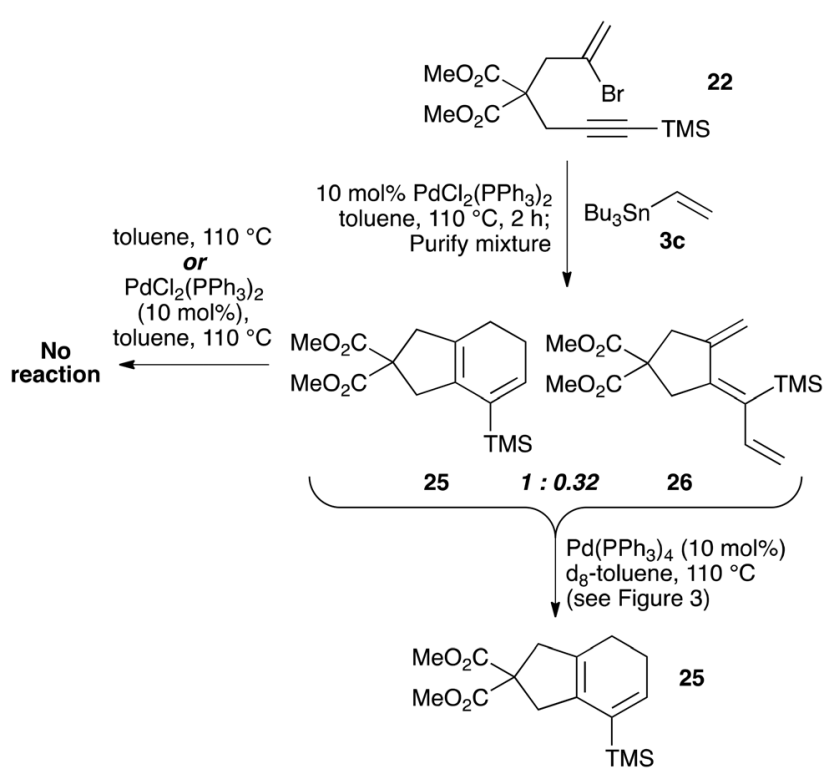

Scheme 5 Exploration of conditions to effect the isomerization of antitriene 26 to bicycle 25 .

vinyltributyltin for two hours, was purified by silica gel chromatography (Scheme 5); the triene 26 in this mixture would be expected to isomerize to give the $\mathbf{2 5}$ upon resubmission to the reaction conditions. Heating the mixture in toluene overnight at $110{ }^{\circ} \mathrm{C}$ in the absence of catalyst led to no conversion 


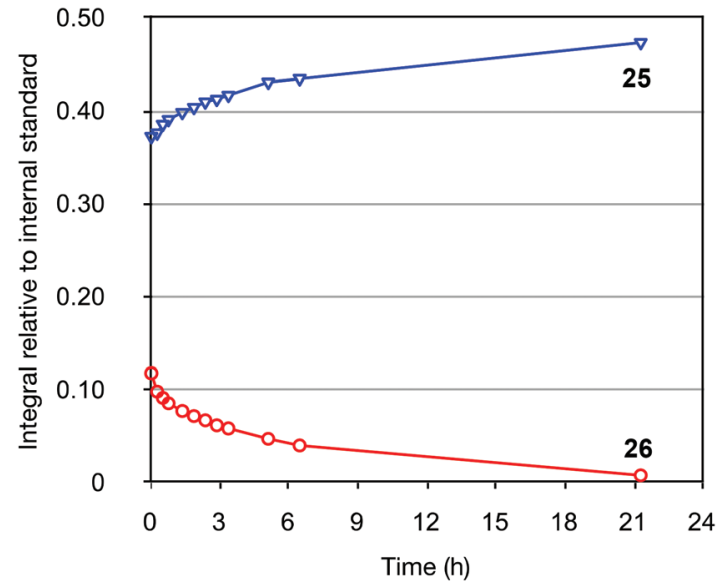

Fig. $4{ }^{1} \mathrm{H}$ NMR spectroscopic monitoring of the conversion of 26 to 25 catalyzed by $\mathrm{Pd}\left(\mathrm{PPh}_{3}\right)_{4}$. 1,4-Dimethoxybenzene was used as internal standard.

of 26 to the bicyclic product 25, with both compounds recovered unchanged after this period (thus ruling out a purely thermal process). Palladium(II) salts have previously been shown to promote alkene isomerisation, ${ }^{21}$ but subjection of the anti-triene to $\mathrm{PdCl}_{2}\left(\mathrm{PPh}_{3}\right)_{2}$ at $110{ }^{\circ} \mathrm{C}$ also led to no reaction. However, heating the mixture in the presence of $\mathrm{Pd}$ $\left(\mathrm{PPh}_{3}\right)_{4}$ for $20 \mathrm{~h}$ led to complete consumption of anti-triene, and by performing this isomerization in $\mathrm{d}_{8}$-toluene with monitoring by ${ }^{1} \mathrm{H}$ NMR spectroscopy in the presence of an internal standard (1,4-dimethoxybenzene), a smooth conversion of 26 to 25 was observed (Fig. 4). This clearly demonstrates that the isomerization of anti-triene to product is not a thermal process, and in fact requires a $\operatorname{Pd}(0)$ catalyst, thus offering some support to our proposed mechanism. At no point do we detect the formation of syn-triene, which lends some weight to our mechanistic hypothesis for the direct conversion of antitrienes to bicyclic products (Scheme 4, although we recognise that any syn-triene formed could electrocyclize rapidly).

\section{Cyclization to 7,4-fused ring cyclobutenes}

In the course of cyclization reactions to form seven-membered rings (including 11c), we had noticed the occasional formation of a different byproduct to those discussed thus far, the production of which seemed highly dependent on the reaction concentration, and quantity of stannane coupling partner. Although this byproduct was not observed under our optimized conditions, the use of $<1.5$ equivalents of stannane, or more dilute reaction conditions (i.e. such that transmetallation would be slowed) increased its formation. In fact, we had first observed such a species in the attempted $8 \pi$-electrocyclic coupling of bromoenyne 27 with stannane 28 (Fig. 5), which resulted in a surprising degree of apparent protodestannylation of 28 (leading to the known diene 29). ${ }^{22}$ We assigned the product formed in this reaction as the 7,4-fused cyclobutene 30 based on detailed analysis by 2D NMR experiments. Specifically, a complete set of HMBC correlations (Fig. 5) was observed between protons H1, H3 and H7, and carbons C2, C8
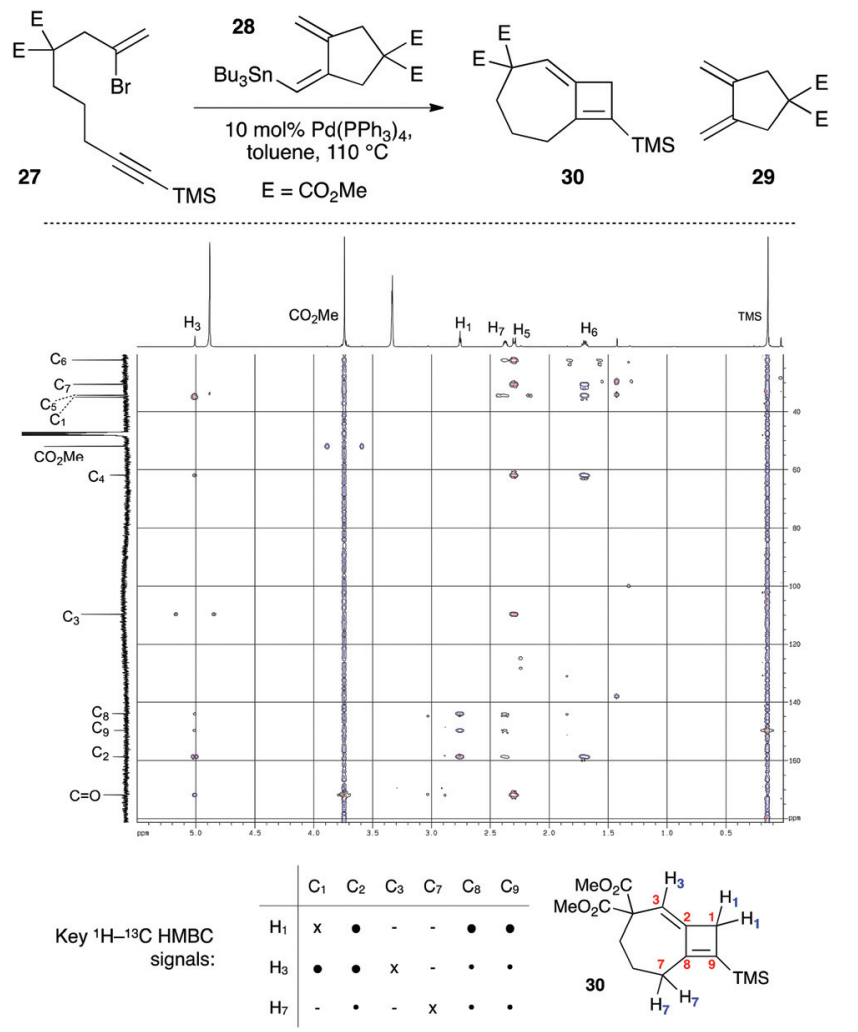

Fig. 5 Initial synthesis of 7,4-fused cyclobutene 30, and key HMBC spectra correlations. $\mathrm{E}=\mathrm{CO}_{2} \mathrm{Me}$. $\bullet=$ strong correlation; $\cdot=$ weak correlation.

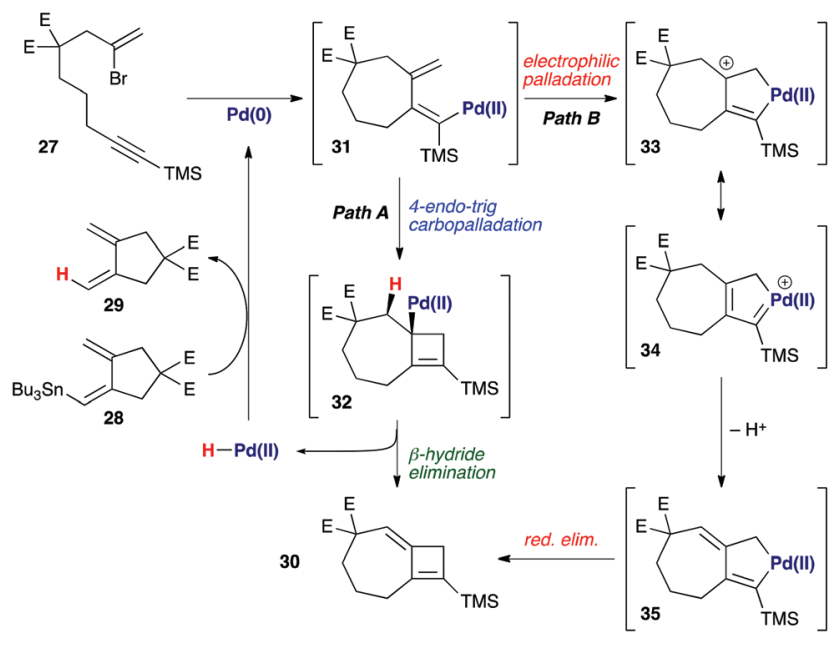

Scheme 6 Possible mechanisms for the formation of 7,4-fused cyclobutene 30. $\mathrm{E}=\mathrm{CO}_{2} \mathrm{Me}$.

and $\mathrm{C} 9$, together with long-range coupling between $\mathrm{H} 1$ and $\mathrm{H} 7$ $\left({ }^{5} J=2.7 \mathrm{~Hz}\right.$; this coupling was also observed in a ${ }^{1} \mathrm{H}-{ }^{1} \mathrm{H}$ COSY spectrum).

The formation of this product is not unreasonable if potential mechanisms for its formation are considered (Scheme 6). Following carbopalladation (31), one possibility would involve a 4-endo-trig carbopalladation (Path A), leading to cyclobutene 


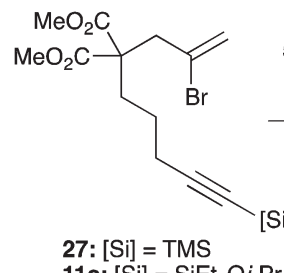

11c: $[\mathrm{Si}]=\mathrm{SiEt}_{2} \mathrm{O} i-\mathrm{Pr}$

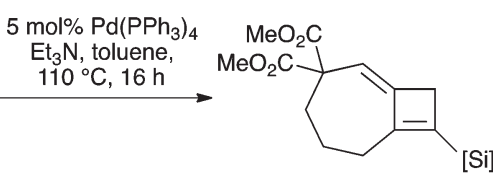

30: $[\mathrm{Si}]=$ TMS: $90 \%$ 36: $[\mathrm{Si}]=\mathrm{SiEt}_{2} \mathrm{O} i-\mathrm{Pr}: 87 \%$

Scheme 7 Heck conditions for formation of 7,4-fused cyclobutenes

32 - a pathway that might be favoured, in spite of ring strain, due to the formation of an allylpalladium intermediate. $\beta$-Hydride elimination would afford the observed product 30, and liberate a palladium(II) hydride species that could be reduced to palladium(0) by transmetallation with 28 , thus leading to the 'protodestannylated' product 29. However, due to a lack of precedent for this mode of carbopalladation, we also consider an electrophilic palladation route feasible (Path B), in which attack by the exo-methylene on the proximal palladium(II) atom leads to palladacycle 33 - which may again be rendered possible by the formation of an allyl cation in this process. Now, loss of a proton generates palladacyclopentene 35 , reductive elimination from which leads to $30 .^{23}$ The resemblance of intermediate 35 to those proposed in enyne cycloisomerization processes is clear; ${ }^{24}$ the proton lost from this pathway could then effect protodestannylation of the coupling partner 28 to afford 29.

Whatever mechanism is operational, it was clear to us that this process overall corresponds to a Heck reaction in which regeneration of the palladium $(0)$ catalyst is mediated by the stannane reagent. This suggested that an amine base might perform a similar role, and to our delight, the use of common Heck conditions (toluene, triethylamine) at just $5 \mathrm{~mol} \%$ catalyst loading indeed led to a high-yielding cyclization of 27 to 30 (90\%, Scheme 7). The more functional bromoenyne 11c was also tested in this chemistry, which gave the corresponding 7,4-fused silylcyclobutene 36 in excellent yield (86\%). This efficient process offers an alternative entry to this type of fused cyclobutene ring system. ${ }^{25}$

\section{Oxidations of silylcyclohexadienes}

To illustrate the potential utility of this chemistry, we subjected the product dienylsilanes to a selection of oxidative transformations. Firstly, a direct Tamao oxidation of the dienylsilane was carried out, ${ }^{26}$ which we hoped would deliver a bicyclic enone. In the case of the isopropoxydimethylsilane 15a, this met with some success (Scheme 8), delivering 37 in moderate yield (43\%). The successful formation of this product, which lacks any olefinic protons, could be confirmed by ${ }^{13} \mathrm{C} \mathrm{NMR}\left(\delta_{\mathrm{C}} 194.9,158.7,134.8 \mathrm{ppm}\right.$ for the enone region) and IR spectroscopy $\left(\nu_{\max } 1667 \mathrm{~cm}^{-1}\right)$. Attempted oxidation of the equivalent diethylisopropoxysilanes proved unsuccessful, potentially due to competing nucleophilic epoxidation of the product enone, which highlights a reactivity benefit of the less-hindered dimethylalkoxysilane group.

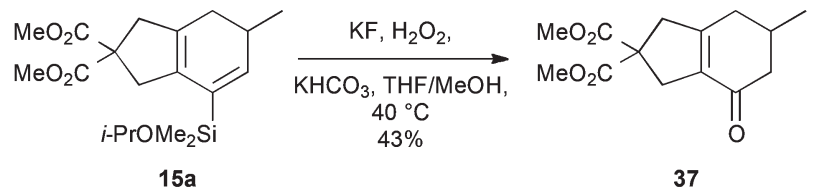

Scheme 8 Bicyclic enone formation.

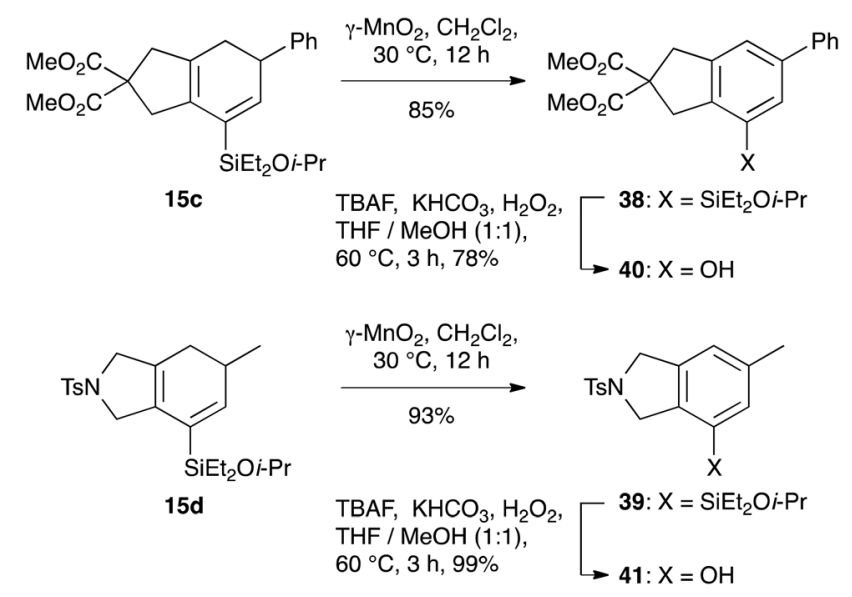

Scheme 9 Oxidation of the silylcyclohexadiene framework.

The silylcyclohexadiene frameworks could also be readily oxidized to the corresponding arylsilanes using manganese dioxide, conditions that we had successfully employed in other work $^{27}$ and which proved superior to the use of other oxidants such as DDQ. The resultant arylsilanes could generally be isolated in excellent yield; two examples are shown in Scheme 9 (38: $88 \%$; 39: 93\%). These arylsilanes show potential for a range of transformations - but here, in keeping with our interests in the synthesis of phenols from arylsilanes, ${ }^{6}$ we chose to investigate Tamao oxidation. Under Tamao conditions (TBAF, $\left.\mathrm{KHCO}_{3}, \mathrm{H}_{2} \mathrm{O}_{2}, 60{ }^{\circ} \mathrm{C}\right),{ }^{28}$ good yields of the corresponding phenols $\mathbf{4 0}$ and $\mathbf{4 1}$ were obtained, thus validating this approach to the synthesis of bi/polycyclic phenols.

\section{Conclusions}

In summary, we have developed efficient routes for the synthesis of functional alkynylsilanes and demonstrated their application in bicyclization cascade reactions. The resultant silylated bicyclic cyclohexadienes are substrates for oxidation to bicyclic enones, arylsilanes, and phenols; the latter process thus affords bicyclic phenols from acyclic precursors in just three steps. Investigations into the mechanism of the cascade cyclization have revealed some unusual palladium-mediated isomerization pathways. Finally, 7,4-fused cyclobutene ring systems, arising from cyclization of a 7-membered exocyclic dienylpalladium complex, could be formed under standard 'Heck' type conditions. Together, these processes underline the rich reactivity - both expected and unexpected - that can be harvested from carbopalladation chemistry. 


\section{Experimental}

\section{General}

Reagents were used as purchased, or purified by standard laboratory techniques. Reaction solvents were purified using an alumina column drying system, and reactions were performed under inert atmosphere unless otherwise stated.

Dimethyl 2-(2-bromoallyl)malonate. To a suspension of $\mathrm{NaH}$ (60\% dispersion in mineral oil, $2.32 \mathrm{~g}, 58.0 \mathrm{mmol}$ ) in THF $(50 \mathrm{~mL})$ at $0{ }^{\circ} \mathrm{C}$ was added dropwise dimethyl malonate (5.52 mL, $48.4 \mathrm{mmol}$ ), and the mixture was stirred for $1 \mathrm{~h} .2,3-$ dibromopropene ( $80 \%$ tech. grade, $5.52 \mathrm{~mL}, 48.4 \mathrm{mmol}$ ) was added to the milky yellow mixture, and stirring was continued for $3 \mathrm{~h}$ until completion of the reaction as monitored by TLC. The reaction was quenched with $\mathrm{NH}_{4} \mathrm{Cl}$ (sat., aq.). The aqueous phase was extracted with $\mathrm{Et}_{2} \mathrm{O}$ and the combined organic extracts washed with brine and dried $\left(\mathrm{MgSO}_{4}\right)$. The solvent was evaporated in vacuo and the crude product purified by distillation at $\left(101-106{ }^{\circ} \mathrm{C}, 1 \mathrm{mmHg}\right)$ to afford the product as a colourless oil $(8.50 \mathrm{~g}, 33.9 \mathrm{mmol}, 70 \%) . R_{\mathrm{f}} 0.22(5: 1$ pet. ether-ether); ${ }^{1} \mathrm{H}$ NMR (500 MHz, $\left.\mathrm{CDCl}_{3}\right) \delta_{\mathrm{H}} 5.69(1 \mathrm{H}, \mathrm{dt}, J=$ 2.0, 1.0 Hz), $5.48(1 \mathrm{H}, \mathrm{d}, J=2.0 \mathrm{~Hz}), 3.89(1 \mathrm{H}, \mathrm{t}, J=7.5 \mathrm{~Hz})$, $3.76(6 \mathrm{H}, \mathrm{s}), 3.03(2 \mathrm{H}, \mathrm{dd}, J=7.5,1.0 \mathrm{~Hz}) ;{ }^{13} \mathrm{C}$ NMR $(125 \mathrm{MHz}$, $\left.\mathrm{CDCl}_{3}\right) \delta_{\mathrm{C}} 168.7,129.2,119.9,52.7,50.4,40.5$. Data in accordance with the literature. ${ }^{29}$

\section{General procedure 1: alkylation of dimethyl 2-(2-bromoallyl)- malonate}

A solution of dimethyl 2-(2-bromoallyl)malonate (1 equiv.) in THF ( $2 \mathrm{~mL} \mathrm{mmol}^{-1}$ ) was added to a stirred suspension of $\mathrm{NaH}$ (60\% dispersion in mineral oil, 1.2 equiv.) and the alkyne electrophile (1.2 equiv.) in THF ( $\left.2 \mathrm{~mL} \mathrm{mmol}^{-1}\right)$. The resulting mixture was stirred at room temperature under argon until completion of the reaction as monitored by TLC. The reaction was quenched by addition of $\mathrm{NH}_{4} \mathrm{Cl}$ (sat., aq.). The aqueous layer was extracted with $\mathrm{Et}_{2} \mathrm{O}$ and the combined organic extracts washed with brine, and dried $\left(\mathrm{MgSO}_{4}\right)$. The solvent was evaporated in vacuo and the crude product purified by flash chromatography to afford the bromoenyne product.

Dimethyl 2-(2-bromoallyl)-2-(prop-2-ynyl)malonate (9a). Synthesised from dimethyl 2-(2-bromoallyl)malonate $(2.90 \mathrm{~g}$, $11.7 \mathrm{mmol}$ ) and propargyl bromide (1.60 $\mathrm{mL}, 14.0 \mathrm{mmol})$ using general procedure 1 . The crude product was purified by flash chromatography ( $5: 1$ pet. ether-ether) to afford 9a as a colourless oil (2.91 g, $10.1 \mathrm{mmol}, 86 \%)$. $R_{\mathrm{f}} 0.31$ (5:1 pet. ether-ether); IR (thin film) $\nu_{\max } / \mathrm{cm}^{-1} 3289,2954,1737$; ${ }^{1} \mathrm{H} \mathrm{NMR}\left(500 \mathrm{MHz}, \mathrm{CDCl}_{3}\right) \delta_{\mathrm{H}} 5.83(1 \mathrm{H}, \mathrm{t}, J=0.6 \mathrm{~Hz}), 5.63(1 \mathrm{H}$, $\mathrm{d}, J=1.6 \mathrm{~Hz}), 3.77(6 \mathrm{H}, \mathrm{s}), 3.31(2 \mathrm{H}, \mathrm{br} \mathrm{s}), 2.93(2 \mathrm{H}, \mathrm{d}, J=$ $2.7 \mathrm{~Hz}), 2.05(1 \mathrm{H}, \mathrm{t}, J=2.7 \mathrm{~Hz}) ;{ }^{13} \mathrm{C} \mathrm{NMR}\left(125 \mathrm{MHz}, \mathrm{CDCl}_{3}\right) \delta_{\mathrm{C}}$ 169.5, 126.1, 122.9, 78.6, 72.1, 56.0, 53.0, 42.9, 22.2; HRMS $\left(\mathrm{ES}^{+}\right.$) calcd for $\mathrm{C}_{11} \mathrm{H}_{13} \mathrm{BrO}_{4}[\mathrm{M}+\mathrm{H}]^{+}$289.0074, found 289.0070. Data in accordance with the literature. ${ }^{8 a}$

Dimethyl 2-(2-bromoallyl)-2-(but-3-ynyl)malonate (9b). Synthesised from dimethyl 2-(2-bromoallyl)malonate (876 mg, $3.49 \mathrm{mmol}$ ) and but-3-ynyl trifluoromethanesulfonate $(847 \mathrm{mg}$, $4.19 \mathrm{mmol}$ ) using general procedure 1 . The crude product was purified by flash chromatography (5:1 pet. ether-ether) to afford $9 \mathrm{~b}$ as a colourless oil (730 mg, $2.41 \mathrm{mmol}, 69 \%) . R_{\mathrm{f}} 0.26$ (5:1 pet. ether-ether); IR (thin film) $\nu_{\max } / \mathrm{cm}^{-1} 3285,2954$, 1730, 1624, 1433, 1201, 1150, 959, 649; ${ }^{1} \mathrm{H}$ NMR $(500 \mathrm{MHz}$, $\left.\mathrm{CDCl}_{3}\right) \delta_{\mathrm{H}} 5.70-5.68(1 \mathrm{H}, \mathrm{m}), 5.61(1 \mathrm{H}, \mathrm{d}, J=1.8 \mathrm{~Hz}), 3.75(6 \mathrm{H}$, s), $3.19(2 \mathrm{H}, \mathrm{d}, J=0.5 \mathrm{~Hz}), 2.30-2.28(2 \mathrm{H}, \mathrm{m}), 2.21-2.19(2 \mathrm{H}$, $\mathrm{m}), 1.97(1 \mathrm{H}, \mathrm{t}, J=2.8 \mathrm{~Hz}) ;{ }^{13} \mathrm{C} \mathrm{NMR}\left(125 \mathrm{MHz}, \mathrm{CDCl}_{3}\right) \delta_{\mathrm{C}}$ $170.4,126.7,122.2$, 82.8, 68.9, 56.4, 52.8, 43.3, 30.7, 14.0; HRMS $\left(\mathrm{ES}^{+}\right.$) calcd for $\mathrm{C}_{12} \mathrm{H}_{15} \mathrm{BrNaO}_{4}[\mathrm{M}+\mathrm{Na}]^{+} 325.0070$, found 325.0062 .

Dimethyl 2-(2-bromoallyl)-2-(pent-4-ynyl)malonate (9c). Synthesised from dimethyl 2-(2-bromoallyl)malonate $(200 \mathrm{mg}$, $0.796 \mathrm{mmol}$ ) and pent-4-ynyl trifluoromethanesulfonate (207 mg, $0.957 \mathrm{mmol}$ ) using general procedure 1. The crude product was purified by flash chromatography $(5: 1$ pet. etherether) to afford 9c as a colourless oil $(227 \mathrm{mg}, 0.716 \mathrm{mmol}$, $90 \%$ ). $R_{\mathrm{f}} 0.26$ (5:1 pet. ether-ether); IR (thin film) $\nu_{\max } / \mathrm{cm}^{-1}$ 3291, 2952, 1731, 1625, 1434, 1278, 1150, 901, 640; ${ }^{1} \mathrm{H}$ NMR $\left(500 \mathrm{MHz}, \mathrm{CDCl}_{3}\right) \delta_{\mathrm{H}} 5.69-5.67(1 \mathrm{H}, \mathrm{m}), 5.59(1 \mathrm{H}, \mathrm{d}, J=$ $1.7 \mathrm{~Hz}), 3.75(6 \mathrm{H}, \mathrm{s}), 3.17(2 \mathrm{H}, \mathrm{s}), 2.21(2 \mathrm{H}, \mathrm{dt}, J=7.0,2.6 \mathrm{~Hz})$, 2.12-2.10 (2H, m), $1.96(1 \mathrm{H}, \mathrm{t}, J=2.6 \mathrm{~Hz}), 1.44-1.42(2 \mathrm{H}, \mathrm{m})$; ${ }^{13} \mathrm{C} \mathrm{NMR}\left(125 \mathrm{MHz}, \mathrm{CDCl}_{3}\right) \delta_{\mathrm{C}} 170.8,126.9,121.9,83.5,68.8$, 56.8, 52.7, 43.1, 30.8, 23.4, 18.5; HRMS $\left(\mathrm{ES}^{+}\right)$calcd for $\mathrm{C}_{13} \mathrm{H}_{17} \mathrm{BrNaO}_{4}[\mathrm{M}+\mathrm{Na}]^{+}$339.0202, found 339.0200.

Dimethyl 2-(2-bromoallyl)-2-(3-(isopropoxydimethylsilyl)prop-2-ynyl)malonate (10a). Method A. To a solution of 9a $(150 \mathrm{mg}, 0.519 \mathrm{mmol})$ in dry THF $(5 \mathrm{~mL})$ at $-78^{\circ} \mathrm{C}$ was added $n$-BuLi (1.6 $\mathrm{M}$ in hexanes, $405 \mu \mathrm{L}, 0.649 \mathrm{mmol}, 1.25$ equiv.), and the mixture was stirred for $20 \mathrm{~min}$. Chloro(diethylamino)dimethylsilane (130 $\mu \mathrm{L}, 0.649 \mathrm{mmol}, 1.25$ equiv.) was added, and the reaction mixture was allowed to warm to rt. When complete as judged by TLC, the reaction was concentrated, diluted with dry pentane, and stirred for $15 \mathrm{~min}$, then filtered through oven-dried Celite. The clear filtrate was evaporated to give the intermediate aminosilane. This was dissolved in $\mathrm{CH}_{2} \mathrm{Cl}_{2}(3 \mathrm{~mL})$ and cooled to $0{ }^{\circ} \mathrm{C}$, then imidazole $(71 \mathrm{mg}$, 1.04 mmol, 2 equiv.), isopropanol ( $80 \mu \mathrm{L}, 1.04 \mathrm{mmol}, 2$ equiv.) and DMAP (cat.) were added to the mixture, which was stirred at $\mathrm{rt}$ for $2 \mathrm{~h}$. The reaction was quenched with $\mathrm{NaHCO}_{3}$ (aq., sat.), the aqueous layer was extracted with $\mathrm{CH}_{2} \mathrm{Cl}_{2}$, and the combined organic extracts were washed with brine, and dried $\left(\mathrm{MgSO}_{4}\right)$. The solvent was evaporated in vacuo and the product was purified by flash chromatography (10:1 pet. ether-ether with $\left.1 \% \mathrm{Et}_{3} \mathrm{~N}\right)$ to afford the $10 \mathrm{a}$ as a colourless oil $(158 \mathrm{mg}$, $0.39 \mathrm{mmol}, 75 \%$ ). $R_{\mathrm{f}} 0.38$ (5:1 pet. ether-ether); IR (thin film) $\nu_{\max } / \mathrm{cm}^{-1} 2360,1658,1568,1382,1369,1290,1030 ;{ }^{1} \mathrm{H}$ NMR $\left(400 \mathrm{MHz}, \mathrm{CDCl}_{3}\right) \delta_{\mathrm{H}} 5.83-5.81(1 \mathrm{H}, \mathrm{m}), 5.63(1 \mathrm{H}, \mathrm{d}, J=1.5$ $\mathrm{Hz}), 4.09(1 \mathrm{H}$, septet, $J=6.1 \mathrm{~Hz}), 3.76(6 \mathrm{H}, \mathrm{s}), 3.30(2 \mathrm{H}, \mathrm{s}), 2.97$ $(2 \mathrm{H}, \mathrm{s}), 1.18(6 \mathrm{H}, \mathrm{d}, J=6.1 \mathrm{~Hz}), 0.22(6 \mathrm{H}, \mathrm{s}) ;{ }^{13} \mathrm{C} \mathrm{NMR}$ $\left(125 \mathrm{MHz}, \mathrm{CDCl}_{3}\right) \delta_{\mathrm{C}} 169.4,126.2,122.7,100.8,87.4,65.9$, $56.0,53.0,43.0,25.4,23.4,0.6$; HRMS $\left(\mathrm{ES}^{+}\right)$calcd for $\mathrm{C}_{16} \mathrm{H}_{25} \mathrm{BrNaO}_{5} \mathrm{Si}[\mathrm{M}+\mathrm{Na}]^{+} 427.0533$, found 427.0547 .

Dimethyl 2-(2-bromoallyl)-2-(3-(isopropoxydimethylsilyl)prop-2-ynyl)malonate (10a). Method B. To a solution of 9a (200 $\mathrm{mg}, 0.691 \mathrm{mmol})$ in $\mathrm{THF}(2 \mathrm{~mL})$ at $-78{ }^{\circ} \mathrm{C}$ was added LiHMDS ( $1 \mathrm{M}$ in hexanes, $830 \mu \mathrm{L}, 0.83 \mathrm{mmol}$ ) and the mixture 
was stirred for $30 \mathrm{~min}$. $\mathrm{ClSiMe}_{2} \mathrm{H}(116 \mu \mathrm{L}, 1.038 \mathrm{mmol})$ was then added, and the reaction was allowed to warm to rt, then stirred until completion as monitored by TLC. The reaction was quenched with $\mathrm{H}_{2} \mathrm{O}$, and the aqueous layer was extracted with ether. The combined organic extracts washed with brine and dried $\left(\mathrm{MgSO}_{4}\right)$. The solvent was evaporated in vacuo and the crude product was purified by flash chromatography $(10: 1$ pet. ether-ether), to afford the intermediate alkynyl hydrosilane as a colourless oil (224 mg, $0.645 \mathrm{mmol}, 93 \%) .{ }^{1} \mathrm{H}$ NMR $\left(400 \mathrm{MHz}, \mathrm{CDCl}_{3}\right) \delta_{\mathrm{H}} 5.65-5.58(1 \mathrm{H}, \mathrm{m}), 5.43(1 \mathrm{H}, \mathrm{d}, J=$ $1.5 \mathrm{~Hz}), 3.87(1 \mathrm{H}$, septet, $J=3.7 \mathrm{~Hz}), 3.56(6 \mathrm{H}, \mathrm{s}), 3.10(2 \mathrm{H}, \mathrm{s})$, $2.76(2 \mathrm{H}, \mathrm{s}), 0.01(6 \mathrm{H}, \mathrm{d}, J=3.7 \mathrm{~Hz}) ;{ }^{13} \mathrm{C}$ NMR $(100 \mathrm{MHz}$, $\left.\mathrm{CDCl}_{3}\right) \delta_{\mathrm{C}} 169.4,126.1,122.8,102.5,86.0,56.0,53.0,42.9,23.6$, -3.0; HRMS $\left(\mathrm{ES}^{+}\right)$calcd for $\mathrm{C}_{13} \mathrm{H}_{19} \mathrm{BrNaO}_{4} \mathrm{Si}[\mathrm{M}+\mathrm{Na}]^{+}$ 369.0128, found 369.0128. To a solution of this hydrosilane $(30 \mathrm{mg}, 0.086 \mathrm{mmol})$ in i-PrOH $(100 \mu \mathrm{L})$ was added $\left[\mathrm{RuCl}_{2}-\right.$ ( $p$-cymene $)]_{2}(0.3 \mathrm{mg}, 0.0004 \mathrm{mmol})$. The reaction was stirred at $\mathrm{rt}$ for $10 \mathrm{~min}$, then concentrated. Pentane $(1 \mathrm{~mL})$ was added, and the crude product was filtered through Celite (ether eluent). Concentration of the filtrate gave 10a as a pale pink oil (35 mg, $0.086 \mathrm{mmol}, 99 \%$ ).

(Diethylamino)diethylchlorosilane. To a solution of dichlorodiethylsilane $(20 \mathrm{~mL}, 134 \mathrm{mmol})$ and anhydrous triethylamine (20.6 mL, $147 \mathrm{mmol})$ in THF at $0{ }^{\circ} \mathrm{C}$ was added a solution of anhydrous diethylamine $(13.8 \mathrm{~mL}, 137 \mathrm{mmol})$ in THF $(6 \mathrm{~mL})$ over $2 \mathrm{~h}$. The resulting beige suspension was warmed to $\mathrm{rt}$ overnight with vigorous stirring maintained. The mixture was then filtered through Celite under $\mathrm{N}_{2}$, the filter cake washed with anhydrous pentane, and the filtrate concentrated in vacuo to give an orange oil. This residue was purified by vacuum distillation (bp 92-94 ${ }^{\circ} \mathrm{C}, 36$ mbar) to afford (diethylamino) diethylchlorosilane as a colourless oil $(17.6 \mathrm{~g}, 90.8 \mathrm{mmol}$, $68 \%) .{ }^{1} \mathrm{H}$ NMR $\left(250 \mathrm{MHz}, \mathrm{CDCl}_{3}\right) \delta_{\mathrm{H}} 2.88(4 \mathrm{H}, \mathrm{q}, J=7.0 \mathrm{~Hz})$, $1.07-0.99(12 \mathrm{H}, \mathrm{m}), 0.90(4 \mathrm{H}, \mathrm{q}, J=6.5 \mathrm{~Hz})$. Data in accordance with literature. ${ }^{30}$

\section{General procedure 2: alkyne silylation with (diethylamino)- diethylchlorosilane}

To a solution of bromoenyne (1 equiv.) in THF ( $4.5 \mathrm{~mL}$ $\left.\mathrm{mmol}^{-1}\right)$ at $-78^{\circ} \mathrm{C}$ under Ar was added LiHMDS $(1 \mathrm{M}$ in THF, 1.5 equiv.). The pale yellow solution was stirred at $-78{ }^{\circ} \mathrm{C}$ for $20 \mathrm{~min}$ and (diethylamino)diethylchlorosilane (1.5 equiv.) was added dropwise to the reaction mixture. After stirring for 30 min, after which time the starting material had been consumed (as monitored by TLC), i-PrOH (4 equiv.), DMAP (cat.) and imidazole (4 equiv.) were added and the reaction was allowed to warm to rt. The reaction was quenched by addition of water, and the aqueous layer was extracted with ether. The combined organic extracts were washed with brine, dried $\left(\mathrm{MgSO}_{4}\right)$, and concentrated. The residue was purified by flash chromatography to afford the silylated bromoenyne.

Dimethyl 2-(2-bromoallyl)-2-(3-(diethyl(isopropoxy)silyl)prop-2-ynyl)malonate (11a). Synthesised from 9a $(500 \mathrm{mg}$, $1.73 \mathrm{mmol})$, LiHMDS (2.60 mL, $2.60 \mathrm{mmol}), \operatorname{ClSiEt}_{2}\left(\mathrm{NEt}_{2}\right)$ $(606 \mu \mathrm{L}, 2.60 \mathrm{mmol})$, i-PrOH $(530 \mu \mathrm{L}, 6.90 \mathrm{mmol})$ and imidazole $(471 \mathrm{mg}, 6.92 \mathrm{mmol})$ using general procedure 2 . The product was purified by flash chromatography $(5: 1$ pet. etherether) to afford 11a as a colourless oil $(701 \mathrm{mg}, 1.62 \mathrm{mmol}$, $94 \%) . \quad R_{\mathrm{f}} 0.26$ (5:1 pet. ether-ether); Anal. calcd for $\mathrm{C}_{18} \mathrm{H}_{29} \mathrm{BrO}_{5} \mathrm{Si}$ : C, 49.88; $\mathrm{H}, 6.74$, found: C, 49.96; H, 6.72; IR (thin film) $\nu_{\max } / \mathrm{cm}^{-1} 2956,2178,1742,1626,1025,733$; ${ }^{1} \mathrm{H}$ NMR $\left(500 \mathrm{MHz}, \mathrm{CDCl}_{3}\right) \delta_{\mathrm{H}} 5.84-5.82(1 \mathrm{H}, \mathrm{m}), 5.63(1 \mathrm{H}, \mathrm{d}$, $J=1.7 \mathrm{~Hz}), 4.10(1 \mathrm{H}$, septet, $J=6.1 \mathrm{~Hz}), 3.76(6 \mathrm{H}, \mathrm{s}), 3.32(2 \mathrm{H}$, s), $3.00(2 \mathrm{H}, \mathrm{s}), 1.18(6 \mathrm{H}, \mathrm{d}, J=6.1 \mathrm{~Hz}), 0.98(6 \mathrm{H}, \mathrm{t}, J=7.9 \mathrm{~Hz})$, $0.62(4 \mathrm{H}$, app. qd, $J=7.9 \mathrm{~Hz}, 2.2 \mathrm{~Hz}) ;{ }^{13} \mathrm{C}$ NMR $(125 \mathrm{MHz}$, $\left.\mathrm{CDCl}_{3}\right) \delta_{\mathrm{C}} 169.3,126.2,122.7,101.6,85.5,66.0,56.1,53.0,42.9$, 25.4, 23.5, 6.8, 6.6; HRMS $\left(\mathrm{ES}^{+}\right)$calcd for $\mathrm{C}_{18} \mathrm{H}_{29} \mathrm{NaBrO}_{5} \mathrm{Si}$ $[\mathrm{M}+\mathrm{Na}]^{+} 455.0860$, found 455.0862 .

Dimethyl 2-(2-bromoallyl)-2-(4-(diethyl(isopropoxy)silyl)but3-ynyl)malonate (11b). Synthesised from 9b $(545 \mathrm{mg}$, $1.80 \mathrm{mmol})$, LiHMDS (2.70 mL, $2.70 \mathrm{mmol}), \mathrm{ClSiEt}_{2}\left(\mathrm{NEt}_{2}\right)(634$ $\mu \mathrm{L}, 2.70 \mathrm{mmol})$, i-PrOH $(550 \mu \mathrm{L}, 7.20 \mathrm{mmol})$ and imidazole (490 mg, $7.20 \mathrm{mmol}$ ) using general procedure 2 . The product was purified by flash chromatography $(5: 1$ pet. ether-ether) to afford $11 \mathrm{~b}$ as a colourless oil (723 $\mathrm{mg}, 1.62 \mathrm{mmol}, 90 \%) ; R_{\mathrm{f}}$ 0.26 ( $5: 1$ Pet. ether-ether); Anal. calcd for $\mathrm{C}_{19} \mathrm{H}_{31} \mathrm{BrO}_{5} \mathrm{Si}$ : C, 51.00; H, 6.98, found: C, 50.92, H; 7.02; IR (thin film) $\nu_{\max } /$ $\mathrm{cm}^{-1}$ 2956, 2173, 1735, 1625, 1435, 1088, 1027, 732; ${ }^{1} \mathrm{H}$ NMR $\left(500 \mathrm{MHz}, \mathrm{CDCl}_{3}\right) \delta_{\mathrm{H}} 5.84-5.82(1 \mathrm{H}, \mathrm{m}), 5.63(1 \mathrm{H}, \mathrm{d}, J=$ $1.7 \mathrm{~Hz}), 4.10(1 \mathrm{H}$, septet, $J=6.1 \mathrm{~Hz}), 3.76(6 \mathrm{H}, \mathrm{s}), 3.18(2 \mathrm{H}, \mathrm{s})$, 2.31-2.29 (2H, m), 2.23-2.24 (2H, m), $1.18(6 \mathrm{H}, \mathrm{d}, J=6.1 \mathrm{~Hz})$, $0.98(6 \mathrm{H}, \mathrm{t}, J=7.9 \mathrm{~Hz}), 0.62(4 \mathrm{H}$, app. qd, $J=7.9 \mathrm{~Hz}, 2.2 \mathrm{~Hz})$; ${ }^{13} \mathrm{C}$ NMR $\left(125 \mathrm{MHz}, \mathrm{CDCl}_{3}\right) \delta_{\mathrm{C}} 170.4,126.6,122.2,106.0,81.9$, 65.9, 56.5, 52.8, 43.4, 30.9, 25.5, 15.3, 6.8, 6.5; HRMS $\left(\mathrm{ES}^{+}\right)$ calcd for $\mathrm{C}_{19} \mathrm{H}_{31} \mathrm{BrNaO}_{5} \mathrm{Si}[\mathrm{M}+\mathrm{Na}]^{+} 469.1016$, found 469.1015 .

Dimethyl 2-(2-bromoallyl)-2-(5-(diethyl(isopropoxy)silyl)pent-4-ynyl)malonate 11c). Synthesised from 9c $(320 \mathrm{mg}$, $1.01 \mathrm{mmol})$, LiHMDS (1.50 mL, $1.50 \mathrm{mmol}), \mathrm{ClSiEt}_{2}\left(\mathrm{NEt}_{2}\right)$ $(355 \mu \mathrm{L}, 1.50 \mathrm{mmol})$, i-PrOH $(306 \mu \mathrm{L}, 4.00 \mathrm{mmol})$ and imidazole $(272 \mathrm{mg}, 4.00 \mathrm{mmol}$ ) using general procedure 2 . The product was purified by flash chromatography $(5: 1$ pet. etherether) to afford $11 \mathrm{c}$ as a colourless oil $(337 \mathrm{mg}, 0.730 \mathrm{mmol}$, $72 \%$ ); $R_{\mathrm{f}} 0.26$ (5:1 pet. ether-ether); Anal. calcd for $\mathrm{C}_{20} \mathrm{H}_{33} \mathrm{BrO}_{5} \mathrm{Si}: \mathrm{C}, 52.05 ; \mathrm{H}, 7.21$, found: C, 51.94; H, 7.30; IR (thin film) $\nu_{\text {max }} / \mathrm{cm}^{-1} 2955,2172,1735,1625,1434,1278,1026$, 732; ${ }^{1} \mathrm{H}$ NMR $\left(500 \mathrm{MHz}, \mathrm{CDCl}_{3}\right) \delta_{\mathrm{H}} 5.68-5.66(1 \mathrm{H}, \mathrm{m}), 5.59$ $(1 \mathrm{H}, \mathrm{d}, J=1.5 \mathrm{~Hz}), 4.14(1 \mathrm{H}$, septet, $J=6.4 \mathrm{~Hz}), 3.75(6 \mathrm{H}, \mathrm{s})$, $3.18(2 \mathrm{H}, \mathrm{s}), 2.29(2 \mathrm{H}, \mathrm{t}, J=7.3 \mathrm{~Hz}), 2.14-2.12(2 \mathrm{H}, \mathrm{m})$, 1.49-1.47 $(2 \mathrm{H}, \mathrm{m}), 1.20(6 \mathrm{H}, \mathrm{d}, J=3.4 \mathrm{~Hz}), 1.00(6 \mathrm{H}, \mathrm{t}, J=$ $6.4 \mathrm{~Hz}), 0.65-0.62(4 \mathrm{H}, \mathrm{m}) ;{ }^{13} \mathrm{C}$ NMR $\left(125 \mathrm{MHz}, \mathrm{CDCl}_{3}\right) \delta_{\mathrm{C}}$ $170.8,127.0,121.9,106.8,81.8,65.9,56.9,52.9,43.2,30.9$, 25.5, 23.4, 19.9, 6.9, 6.6; HRMS (ES ${ }^{+}$) calcd for $\mathrm{C}_{20} \mathrm{H}_{33} \mathrm{BrNaO}_{5} \mathrm{Si}$ $[\mathrm{M}+\mathrm{Na}]^{+} 483.1173$, found 483.1179 .

$N$-(2-Bromoallyl)-4-methyl- $N$-(prop-2-ynyl)benzene sulfonamide. To a mixture of $N$-(2-bromoallyl)-4-methylbenzenesulfonamide $(1.00 \mathrm{~g}, 3.45 \mathrm{mmol})$ and $\mathrm{K}_{2} \mathrm{CO}_{3}(953 \mathrm{mg}$, $6.89 \mathrm{mmol})$ in acetone $(10 \mathrm{~mL})$ was added propargyl bromide ( $80 \%$ in toluene, $460 \mu \mathrm{L}, 4.14 \mathrm{mmol}$ ). The reaction mixture was stirred at $60{ }^{\circ} \mathrm{C}$ for $12 \mathrm{~h}$, then it was cooled to rt and quenched with water. The aqueous layer was extracted with $\mathrm{Et}_{2} \mathrm{O}$, then the combined organic layers were dried $\left(\mathrm{MgSO}_{4}\right)$ and concentrated in vacuo. The crude product was purified by 
flash chromatography ( $2: 1$ pet. ether-ether) to afford the title compound as a colourless oil (903 mg, $2.75 \mathrm{mmol}, 80 \%$ ); $R_{\mathrm{f}} 0.35$ (2:1 pet. ether-ether); IR (thin film) $\nu_{\max } / \mathrm{cm}^{-1} 3280$, 1629, 1344, 1181, 1150, 892, 679; ${ }^{1} \mathrm{H}$ NMR (500 MHz, $\mathrm{CDCl}_{3}$ ) $\delta_{\mathrm{H}} 7.75(2 \mathrm{H}, \mathrm{d}, J=8.1 \mathrm{~Hz}), 7.31(2 \mathrm{H}, \mathrm{d}, J=8.1 \mathrm{~Hz}), 5.97-5.95$ $(1 \mathrm{H}, \mathrm{m}), 5.69-5.67(1 \mathrm{H}, \mathrm{m}), 4.13(2 \mathrm{H}, \mathrm{d}, J=2.3 \mathrm{~Hz}), 4.08(2 \mathrm{H}$, s), $2.44(3 \mathrm{H}, \mathrm{s}), 2.05(1 \mathrm{H}, \mathrm{t}, J=2.3 \mathrm{~Hz}) ;{ }^{13} \mathrm{C} \mathrm{NMR}(125 \mathrm{MHz}$, $\left.\mathrm{CDCl}_{3}\right) \delta_{\mathrm{C}} 143.9,135.8,129.6,127.7,126.9,120.5,76.0,74.2$, 53.8, 36.1, 21.6; HRMS $\left(\mathrm{ES}^{+}\right)$calcd for $\mathrm{C}_{14} \mathrm{H}_{18} \mathrm{BrNNaO}_{3} \mathrm{~S}$ $[\mathrm{M}+\mathrm{MeOH}+\mathrm{Na}]^{+}$382.0083, found 382.0077.

$N$-(2-Bromoallyl)- $N$-(3-(diethyl(isopropoxy)silyl)prop-2-ynyl)4-methylbenzene sulfonamide (12). Synthesised from $\mathrm{N}-(2-$ bromoallyl)-4-methyl- $N$-(prop-2-ynyl)benzene sulfonamide (150 mg, $0.457 \mathrm{mmol})$, LiHMDS (686 $\mu \mathrm{L}, 0.686 \mathrm{mmol}$ ), $\mathrm{ClSiEt}_{2}\left(\mathrm{NEt}_{2}\right) \quad(160 \mu \mathrm{L}, 0.686 \mathrm{mmol}), \quad \mathrm{i}-\mathrm{PrOH}(140 \mu \mathrm{L}$, $1.80 \mathrm{mmol}$ ) and imidazole (125 mg, $1.84 \mathrm{mmol}$ ) using general procedure 2 . The product was purified by flash chromatography ( $5: 1$ pet. ether-ether) to afford 12 as a colourless oil (107 mg, $0.226 \mathrm{mmol}, 50 \%$ ); $R_{\mathrm{f}} 0.26$ (5:1 pet. ether-ether); Anal. calcd for $\mathrm{C}_{20} \mathrm{H}_{30} \mathrm{BrNO}_{3} \mathrm{SSi}$ : C, 50.84; H, 6.40; N, 2.96, found: C, 50.90; H, 6.32; N, 2.95. IR (thin film) $\nu_{\max } / \mathrm{cm}^{-1} 2960$, 1353, 1163, 1119, 1092, 1002, 899, 734, 661; ${ }^{1} \mathrm{H}$ NMR $\left(400 \mathrm{MHz}, \mathrm{CDCl}_{3}\right) \delta_{\mathrm{H}} 7.77(2 \mathrm{H}, \mathrm{d}, J=8.1 \mathrm{~Hz}), 7.33(2 \mathrm{H}, \mathrm{d}, J=$ $8.1 \mathrm{~Hz}), 5.98(1 \mathrm{H}, \mathrm{d}, J=1.8 \mathrm{~Hz}), 5.72(1 \mathrm{H}, \mathrm{d}, J=1.8 \mathrm{~Hz}), 4.23$ $(2 \mathrm{H}, \mathrm{s}), 4.11(2 \mathrm{H}, \mathrm{s}), 3.95(1 \mathrm{H}, \mathrm{sept}, J=6.0 \mathrm{~Hz}), 2.45(3 \mathrm{H}, \mathrm{s})$, $1.14(6 \mathrm{H}, \mathrm{d}, J=6.0 \mathrm{~Hz}), 0.89(6 \mathrm{H}, \mathrm{t}, J=7.8 \mathrm{~Hz}), 0.51(4 \mathrm{H}, \mathrm{q}, J=$ $7.8 \mathrm{~Hz}) ;{ }^{13} \mathrm{C} \mathrm{NMR}\left(125 \mathrm{MHz}, \mathrm{CDCl}_{3}\right) \delta_{\mathrm{C}} 144.0,136.3,130.4$, 130.1, 128.1, 119.7, 98.9, 66.5, 45.4, 41.0, 38.6, 26.2, 25.8, 7.8, 7.0; HRMS $\left(\mathrm{ES}^{+}\right)$calcd for $\mathrm{C}_{20} \mathrm{H}_{30} \mathrm{BrNNaO}_{3} \mathrm{SSi}[\mathrm{M}+\mathrm{Na}]^{+}$ 494.0791, found 494.0789.

2-Bromo-3-(prop-2-ynyloxy)prop-1-ene. To a solution of $\mathrm{NaH}$ (60\% in mineral oil, $1.50 \mathrm{~g}, 35.8 \mathrm{mmol})$ in THF $(10 \mathrm{~mL})$ at $0{ }^{\circ} \mathrm{C}$ was added propargyl alcohol $(1.00 \mathrm{~mL}, 17.0 \mathrm{mmol})$ and the reaction mixture was stirred for $30 \mathrm{~min}$. 2,3-Dibromopropene $(1.50 \mathrm{~mL}, 14.3 \mathrm{mmol})$ was slowly added, then the reaction mixture was allowed to warm to rt and stirred for $12 \mathrm{~h}$. The reaction was quenched by addition of water and the aqueous layer was extracted with $\mathrm{Et}_{2} \mathrm{O}$; the combined organic extracts were washed with brine and dried $\left(\mathrm{MgSO}_{4}\right)$. The solvent was evaporated in vacuo and the crude product purified by flash chromatography (5:1 pet. ether-ether) to afford the 2-bromo3-(prop-2-ynyloxy)prop-1-ene as a colourless oil (2.15 g, $12.3 \mathrm{mmol}, 86 \%$ ); $R_{\mathrm{f}} 0.26$ (5:1 pet. ether-ether); IR (thin film) $\nu_{\max } / \mathrm{cm}^{-1} 3300,2923,2130,1639,1443,1162,1086,899,668$; ${ }^{1} \mathrm{H}$ NMR $\left(400 \mathrm{MHz}, \mathrm{CDCl}_{3}\right) \delta_{\mathrm{H}} 5.97-5.95(1 \mathrm{H}, \mathrm{m}), 5.67-5.65$ (1H, m), 4.23-4.19 (4H, m), $2.47(1 \mathrm{H}, \mathrm{t}, J=2.4 \mathrm{~Hz}) ;{ }^{13} \mathrm{C} \mathrm{NMR}$ $\left(125 \mathrm{MHz}, \mathrm{CDCl}_{3}\right) \delta_{\mathrm{C}} 128.4,118.7,78.8,75.1,73.3,57.0$; HRMS $\left(\mathrm{ES}^{+}\right)$calcd for $\mathrm{C}_{6} \mathrm{H}_{7} \mathrm{BrO}[\mathrm{M}+\mathrm{H}]^{+}$173.9681, found 173.9679 . Data in accordance with the literature. ${ }^{31}$

(3-(2-Bromoallyloxy)prop-1-ynyl)diethyl(isopropoxy)silane (13). Synthesised from 2-bromo-3-(prop-2-ynyloxy) prop-1-ene (500 mg, $2.86 \mathrm{mmol}$ ), LiHMDS (4.30 mL, $4.30 \mathrm{mmol}^{\text {) }, \mathrm{ClSiEt}_{2}-}$ $\left(\mathrm{NEt}_{2}\right)(1.00 \mathrm{~mL}, 4.30 \mathrm{mmol})$, i-PrOH $(875 \mu \mathrm{L}, 11.4 \mathrm{mmol})$ and imidazole $(778 \mathrm{mg}, 11.4 \mathrm{mmol}$ ) using general procedure 2 . The product was purified by flash chromatography $(5: 1$ pet. etherether) to afford 13 as a colourless oil $(537 \mathrm{mg}, 1.68 \mathrm{mmol}$,
$59 \%$ ); $R_{\mathrm{f}} 0.26$ (5:1 pet. ether-ether); IR (thin film) $\nu_{\max } / \mathrm{cm}^{-1}$ 2969, 1461, 1380, 1240, 1122, 1088, 878, 734; ${ }^{1} \mathrm{H}$ NMR $\left(400 \mathrm{MHz}, \mathrm{CDCl}_{3}\right) \delta_{\mathrm{H}} 5.93(1 \mathrm{H}, \mathrm{d}, J=1.7 \mathrm{~Hz}), 5.64-5.62(1 \mathrm{H}$, $\mathrm{m}), 4.23(2 \mathrm{H}, \mathrm{s}), 4.21(2 \mathrm{H}, \mathrm{s}), 4.12(1 \mathrm{H}$, septet, $J=6.1 \mathrm{~Hz}), 1.17$ $(6 \mathrm{H}, \mathrm{d}, J=6.1 \mathrm{~Hz}), 0.96(6 \mathrm{H}, \mathrm{t}, J=7.8 \mathrm{~Hz}), 0.58(4 \mathrm{H}, \mathrm{q}, J=$ $7.9 \mathrm{~Hz}) ;{ }^{13} \mathrm{C} \mathrm{NMR}\left(125 \mathrm{MHz}, \mathrm{CDCl}_{3}\right) \delta_{\mathrm{C}} 128.7,118.8,101.3$, 89.1, 73.3, 66.3, 57.9, 25.7, 6.8, 6.7; HRMS $\left(\mathrm{ES}^{+}\right)$calcd for $\mathrm{C}_{13} \mathrm{H}_{23} \mathrm{BrNaO}_{2} \mathrm{Si}[\mathrm{M}+\mathrm{Na}]^{+}$341.0543, found 341.0531.

\section{General procedure 3: cyclisation of bromoenynes to silylcyclohexyldienes}

$\mathrm{PdCl}_{2}\left(\mathrm{PPh}_{3}\right)_{2}$ (0.1 equiv.) was added to a degassed solution of bromoenyne (1 equiv.) and vinyl stannane (1.5-1.7 equiv.) in toluene $\left(20 \mathrm{~mL} \mathrm{mmol}{ }^{-1}\right)$ under argon. The reaction mixture was heated to reflux $\left(110^{\circ} \mathrm{C}\right)$ until completion as monitored by TLC and/or ${ }^{1} \mathrm{H}$ NMR spectroscopic analysis of an aliquot. After concentration, the crude mixture was purified by flash chromatography to obtain the bicyclic diene.

Dimethyl 7-(isopropoxydimethylsilyl)-5-methyl-4,5-dihydro$\mathbf{1 H}$-indene-2,2(3H)-dicarboxylate (15a). Synthesised from 10a (23.9 $\mathrm{mg}, 0.0590 \mathrm{mmol}$ ) and (E)-tributyl(prop-1-enyl)stannane 3a (29.3 mg, $0.0885 \mathrm{mmol}$ ) using general procedure 3 . The product was purified by flash chromatography $(5: 1$ pet. etherether) to afford 15a as a colourless oil $(20 \mathrm{mg}, 0.0546 \mathrm{mmol}$, $92 \%$ ); $R_{\mathrm{f}} 0.33$ (5:1 pet. ether-ether); IR (thin film) $\nu_{\max } / \mathrm{cm}^{-1}$ 2358, 1737, 1252, 1024, 890, 822, 781; ${ }^{1} \mathrm{H}$ NMR $(500 \mathrm{MHz}$, $\left.\mathrm{CDCl}_{3}\right) \delta_{\mathrm{H}} 5.95(1 \mathrm{H}, \mathrm{d}, J=3.3 \mathrm{~Hz}, \mathrm{H} 6), 3.95(1 \mathrm{H}$, septet, $J=$ $6.3 \mathrm{~Hz}, \mathrm{CHMe}$ ), $3.74\left(3 \mathrm{H}, \mathrm{s}, \mathrm{CO}_{2} \mathrm{Me}\right), 3.74\left(3 \mathrm{H}, \mathrm{s}, \mathrm{CO}_{2} \mathrm{Me}\right)$, 3.67-3.65 (1H, m, H5), 3.20 (2H, br s, H3), 3.03-3.01 (1H, m, H4), 2.96-2.94 (1H, m, H'4), 2.46-2.44 (1H, m, H3), 2.20-2.18 $\left(1 \mathrm{H}, \mathrm{m}, \mathrm{H}^{\prime} 3\right), 1.13\left(3 \mathrm{H}, \mathrm{d}, J=6.3 \mathrm{~Hz}, \mathrm{CHMe}_{2}\right), 1.12(3 \mathrm{H}, \mathrm{d}, J=$ $\left.6.3 \mathrm{~Hz}, \mathrm{CHMe}_{2}\right), 1.04(3 \mathrm{H}, \mathrm{d}, J=7.1 \mathrm{~Hz}, \mathrm{Me}), 0.23(6 \mathrm{H}, \mathrm{s}$, $\left.\mathrm{SiMe}_{2}\right) ;{ }^{13} \mathrm{C} \mathrm{NMR}\left(125 \mathrm{MHz}, \mathrm{CDCl}_{3}\right) \delta_{\mathrm{C}} 172.8,172.8,143.9$, 132.1, 131.3, 131.1, 65.1, 58.5, 52.7, 52.7, 43.0, 41.7, 31.1, 30.0, $25.6,20.1,-0.90 ;$ HRMS $\left(\mathrm{ES}^{+}\right)$calcd for $\mathrm{C}_{19} \mathrm{H}_{30} \mathrm{NaO}_{5} \mathrm{Si}$ $[\mathrm{M}+\mathrm{Na}]^{+}$389.1743, found 389.1755.

Dimethyl 7-(isopropoxydimethylsilyl)-5-phenyl-4,5-dihydro$\mathbf{1 H}$-indene-2,2(3H)-dicarboxylate (15b). Synthesised from 10a (26.6 $\mathrm{mg}, 0.0656 \mathrm{mmol}$ ) and (E)-tributyl(styryl)stannane $\mathbf{3 b}$ (38.8 $\mathrm{mg}, 0.0987 \mathrm{mmol}$ ) using general procedure 3 . The product was purified by flash chromatography ( $5: 1$ pet. etherether) to afford 15b as a colourless oil (27.4 mg, $0.0639 \mathrm{mmol}$, 97\%); $R_{\mathrm{f}} 0.30$ (5:1 pet. ether-ether); IR (thin film) $\nu_{\max } / \mathrm{cm}^{-1}$ 2391, 1737, 1434, 1367, 1252, 1023, 782; ${ }^{1} \mathrm{H}$ NMR (500 MHz, $\left.\mathrm{CDCl}_{3}\right) \delta_{\mathrm{H}} 7.30(2 \mathrm{H}, \mathrm{m}, \mathrm{ArH}), 7.24(3 \mathrm{H}, \mathrm{m}, \mathrm{ArH}), 6.10(1 \mathrm{H}, \mathrm{d}, J=$ $3.1 \mathrm{~Hz}, \mathrm{H6}), 3.99(1 \mathrm{H}$, septet, $J=6.2 \mathrm{~Hz}, \mathrm{CHMe}), 3.76(3 \mathrm{H}, \mathrm{s}$, $\mathrm{CO}_{2} \mathrm{Me}$ ), $3.74\left(3 \mathrm{H}, \mathrm{s}, \mathrm{CO}_{2} \mathrm{Me}\right.$ ), 3.65-3.63 (1H, m, H5), 3.28-3.26 (2H, m, H1), $3.10(1 \mathrm{H}, \mathrm{d}, J=17.4 \mathrm{~Hz}, \mathrm{H} 4), 2.94(1 \mathrm{H}, \mathrm{d}, J=$ $\left.17.4 \mathrm{~Hz}, \mathrm{H}^{\prime} 4\right), 2.45-2.43$ (1H, m, H3), 2.29-2.27 (1H, m, H'3), $1.16\left(3 \mathrm{H}, \mathrm{d}, J=6.2 \mathrm{~Hz}, \mathrm{CHMe}_{2}\right), 1.14(3 \mathrm{H}, \mathrm{d}, J=6.2 \mathrm{~Hz}$, $\left.\mathrm{CHMe}_{2}\right), 0.25\left(6 \mathrm{H}, \mathrm{s}, \mathrm{SiMe} e_{2}\right) ;{ }^{13} \mathrm{C}$ NMR $\left(125 \mathrm{MHz}, \mathrm{CDCl}_{3}\right) \delta_{\mathrm{C}}$ $172.7,145.4,140.7,133.4,131.7,131.1,128.5,127.6,126.3$, 65.2, 58.5, 52.7, 42.9, 41.2, 41.7, 32.0, 25.6, -0.9; HRMS $\left(\mathrm{ES}^{+}\right)$ calcd for $\mathrm{C}_{24} \mathrm{H}_{32} \mathrm{NaO}_{5} \mathrm{Si}[\mathrm{M}+\mathrm{Na}]^{+} 451.1892$, found 451.1911 .

Dimethyl 7-(diethyl(isopropoxy)silyl)-5-phenyl-4,5-dihydro$1 H$-indene-2,2(3H)-dicarboxylate (15c). Synthesised from 11a 
(300 $\mathrm{mg}, \quad 0.670 \mathrm{mmol}$ ) and (E)-tributyl(styryl)stannane $\mathbf{3 b}$ (435 mg, $1.11 \mathrm{mmol}$ ) using general procedure 3 . The crude product was purified by flash chromatography $(5: 1$ pet. etherether) to afford $15 \mathrm{c}$ as a colourless oil (237 $\mathrm{mg}, 0.519 \mathrm{mmol}$, $77 \%$ ); $R_{\mathrm{f}} 0.42$ (5:1 pet. ether-ether); IR (thin film) $\nu_{\max } / \mathrm{cm}^{-1}$ 2955, 1736, 1434, 1381, 1243, 1005, 874, 730, 699; ${ }^{1} \mathrm{H}$ NMR $(400 \mathrm{MHz}, \mathrm{CDCl} 3) \delta_{\mathrm{H}} 7.32-7.30(2 \mathrm{H}, \mathrm{m}, \mathrm{ArH}), 7.27-7.23(3 \mathrm{H}$, $\mathrm{m}, \mathrm{ArH}), 6.12-6.10(1 \mathrm{H}, \mathrm{m}, \mathrm{H} 6), 4.01(1 \mathrm{H}$, septet, $J=6.2 \mathrm{~Hz}$, $\mathrm{CH} \mathrm{Me}_{2}$ ), $3.76\left(3 \mathrm{H}, \mathrm{s}, \mathrm{CO}_{2} \mathrm{Me}\right), 3.73\left(3 \mathrm{H}, \mathrm{s}, \mathrm{CO}_{2} \mathrm{Me}\right), 3.64-3.62$ (1H, m, H5), 3.25 (2H, br s, H3), 3.10 (1H, d, $J=17.5 \mathrm{~Hz}, \mathrm{H} 1)$, $2.94\left(1 \mathrm{H}, \mathrm{d}, J=17.5 \mathrm{~Hz}, \mathrm{H}^{\prime} 1\right), 2.45-2.43$ (1H, m, H4), 2.27-2.25 $\left(1 \mathrm{H}, \mathrm{m}, \mathrm{H}^{\prime} 4\right), 1.16\left(3 \mathrm{H}, \mathrm{d}, J=6.2 \mathrm{~Hz}, \mathrm{CHMe} e_{2}\right), 1.15(3 \mathrm{H}, \mathrm{d}, J=$ $\left.6.2 \mathrm{~Hz}, \mathrm{CHMe}_{2}\right), 1.00-0.95\left(6 \mathrm{H}, \mathrm{m}, \mathrm{SiCH}_{2} \mathrm{Me}\right), 0.77-0.74(4 \mathrm{H}$, $\left.\mathrm{m}, \mathrm{SiCH}_{2} \mathrm{Me}\right) ;{ }^{13} \mathrm{C} \mathrm{NMR}\left(125 \mathrm{MHz}, \mathrm{CDCl}_{3}\right) \delta_{\mathrm{C}} 172.8,172.7$, $145.5,141.3$, 131.8, 131.5, 130.9, 128.5, 127.6, 126.3, 65.2, 58.5, 52.7, 52.7, 42.9, 42.2, 41.8, 32.1, 25.7, 25.6, 6.8, 5.0, 4.9; HRMS $\left(\mathrm{ES}^{+}\right)$calcd for $\mathrm{C}_{27} \mathrm{H}_{40} \mathrm{NaO}_{6} \mathrm{Si}[\mathrm{M}+\mathrm{MeOH}+\mathrm{Na}]^{+}$511.2486, found 511.2432 .

7-(Diethyl(isopropoxy)silyl)-5-methyl-2-tosyl-2,3,4,5-tetrahydro$\mathbf{1 H}$-isoindole (15d). Synthesised from $12(50.0 \mathrm{mg}$, $0.106 \mathrm{mmol}$ ) and (E)-tributyl(prop-1-enyl)stannane 3a (60.0 mg, $0.181 \mathrm{mmol}$ ) using general procedure 3 . The product was purified by flash chromatography ( $5: 1$ pet. ether-ether) to afford 15d as a colourless oil $(29.0 \mathrm{mg}, 0.0670 \mathrm{mmol}, 63 \%) ; R_{\mathrm{f}}$ 0.29 (5:1 pet. ether-ether); IR (thin film) $\nu_{\max } / \mathrm{cm}^{-1} 2958$, 1436, 1378, 1230, 1015, 874, 730, 699; ${ }^{1} \mathrm{H}$ NMR $(500 \mathrm{MHz}$, $\left.\mathrm{CDCl}_{3}\right) \delta_{\mathrm{H}} 7.72(2 \mathrm{H}, \mathrm{d}, J=8.0 \mathrm{~Hz}, \mathrm{ArH}), 7.31(2 \mathrm{H}, \mathrm{d}, J=8.0 \mathrm{~Hz}$, $\mathrm{ArH}), 5.93(1 \mathrm{H}, \mathrm{d}, J=3.5 \mathrm{~Hz}, \mathrm{H} 6), 4.22-4.20$ (2H, m, H1), 4.11-4.00 (2H, m, H3), $3.95(1 \mathrm{H}$, septet, $J=5.9 \mathrm{~Hz}, \mathrm{CHMe}$ ), $2.42(4 \mathrm{H}, \mathrm{s}, \mathrm{H} 5, \mathrm{ArMe}), 2.15(1 \mathrm{H}, \mathrm{dd}, J=17.0,8.5 \mathrm{~Hz}, \mathrm{H} 5)$, 1.81-1.73 (1H, m, H'5), $1.13(3 \mathrm{H}, \mathrm{d}, J=6.0 \mathrm{~Hz}, \mathrm{CHMe} 2), 1.11$ $\left(3 \mathrm{H}, \mathrm{d}, J=6.0 \mathrm{~Hz}, \mathrm{CHMe} e_{2}\right), 1.02(3 \mathrm{H}, \mathrm{d}, J=7.1 \mathrm{~Hz}, \mathrm{CHMe}), 0.89$ (6H, app. td, $\left.J=8.0,1.7 \mathrm{~Hz}, \mathrm{SiCH}_{2} \mathrm{Me}\right), 0.68-0.65(4 \mathrm{H}, \mathrm{m}$, $\left.\mathrm{SiCH}_{2} \mathrm{Me}\right) ;{ }^{13} \mathrm{C}$ NMR $\left(125 \mathrm{MHz}, \mathrm{CDCl}_{3}\right) \delta_{\mathrm{C}} 145.1,143.2,134.4$, 129.9, 129.6, 128.1, 127.8, 127.5, 65.3, 56.3, 55.4, 29.8, 28.7, 25.7, 25.7, 21.5, 19.9, 6.8, 5.0, 5.0; HRMS $\left(\mathrm{ES}^{+}\right)$calcd for $\mathrm{C}_{23} \mathrm{H}_{35} \mathrm{NNaO}_{3} \mathrm{SSi}[\mathrm{M}+\mathrm{Na}]^{+}$456.1999, found 456.2000.

Diethyl(isopropoxy)(6-methyl-1,3,6,7-tetrahydroisobenzofuran4-yl)silane (15e). Synthesised from $13(50.0 \mathrm{mg}, 0.157 \mathrm{mmol})$ and (E)-tributyl(prop-1-enyl)stannane 3a $\quad(88.1 \quad \mathrm{mg}$, $0.266 \mathrm{mmol}$ ) using general procedure 3 . The crude product was purified by flash chromatography ( $5: 1$ pet. ether-ether) to afford 15e as a colourless oil $(10.0 \mathrm{mg}, 0.0356 \mathrm{mmol}, 23 \%) ; R_{\mathrm{f}}$ 0.29 (5:1 pet. ether-ether); IR (thin film) $\nu_{\max } / \mathrm{cm}^{-1} 2955$, 1732, 1463, 1210, 866; ${ }^{1} \mathrm{H}$ NMR $\left(500 \mathrm{MHz} \mathrm{CDCl}_{3}\right) \delta_{\mathrm{H}} 5.99(1 \mathrm{H}$, $\mathrm{d}, J=3.3 \mathrm{~Hz}, \mathrm{H} 5), 4.75-4.73(2 \mathrm{H}, \mathrm{m}, \mathrm{H} 1), 4.60-4.58(2 \mathrm{H}, \mathrm{m}$, H3), $3.99(1 \mathrm{H}$, septet, $J=6.0 \mathrm{~Hz}, \mathrm{CHMe}), 2.59-2.48(1 \mathrm{H}, \mathrm{m}$, H8), 2.26 (1H, dd, $J=17.0,9.0 \mathrm{~Hz}, \mathrm{H} 7), 1.92-1.84(1 \mathrm{H}, \mathrm{m}, \mathrm{H} 7)$, $\left.1.16(3 \mathrm{H}, \mathrm{d}, J=6.0 \mathrm{~Hz}, \mathrm{CHMe})_{2}\right), 1.15(3 \mathrm{H}, \mathrm{d}, J=6.0 \mathrm{~Hz}$, $\left.\mathrm{CHMe}_{2}\right), 1.09$ (3H, d, $\left.J=7.0 \mathrm{~Hz}, \mathrm{CHMe}\right), 0.94(6 \mathrm{H}, \mathrm{t}, J=7.9 \mathrm{~Hz}$, $\mathrm{SiCH}_{2} \mathrm{Me}$ ), 0.75-0.65 (4H, m, $\left.\mathrm{SiCH}_{2} \mathrm{Me}\right) ;{ }^{13} \mathrm{C}$ NMR $(125 \mathrm{MHz}$, $\left.\mathrm{CDCl}_{3}\right) \delta_{\mathrm{C}} 144.6,131.3,129.7,127.4,76.3$, 75.7, 65.2, 29.9, 27.7, 25.7, 20.1, 6.7, 4.9; HRMS $\left(\mathrm{ES}^{+}\right)$calcd for $\mathrm{C}_{16} \mathrm{H}_{28} \mathrm{NaO}_{2} \mathrm{Si}$ $[\mathrm{M}+\mathrm{Na}]^{+}$303.1751, found 303.1749.

Dimethyl 5-(diethyl(isopropoxy)silyl)-7-methyl-3,4,7,8-tetrahydronaphthalene-2,2(1H)-dicarboxylate

(15f). Synthesised from 11b (100 mg, $0.223 \mathrm{mmol}$ ) and (E)-tributyl(prop-1-enyl)stannane 3a (126 mg, $0.381 \mathrm{mmol}$ ) using general procedure 3 . The product was purified by flash chromatography $(5: 1$ pet. ether-ether) to afford $\mathbf{1 5 f}$ as a colourless oil $(68.0 \mathrm{mg}$, $0.166 \mathrm{mmol}, 75 \%) ; R_{\mathrm{f}} 0.52$ (5:1 pet. ether-ether); IR (thin film) $\nu_{\max } / \mathrm{cm}^{-1} 2956,1735,1435,1250,1170,1121,1083$, 1018, 872, 731; ${ }^{1} \mathrm{H}$ NMR (500 MHz, $\left.\mathrm{CDCl}_{3}\right) \delta_{\mathrm{H}} 5.99(1 \mathrm{H}, \mathrm{d}, J=$ $3.4 \mathrm{~Hz}, \mathrm{H} 6), 3.94(1 \mathrm{H}$, sept, $J=6.1 \mathrm{~Hz}, \mathrm{OCHMe} 2), 3.72(3 \mathrm{H}, \mathrm{s}$, $\mathrm{CO}_{2} \mathrm{Me}$ ), $3.71\left(3 \mathrm{H}, \mathrm{s}, \mathrm{CO}_{2} \mathrm{Me}\right), 2.60(2 \mathrm{H}, \mathrm{m}, \mathrm{H} 1), 2.31-2.29(3 \mathrm{H}$, $\mathrm{m}, \mathrm{H} 4$ and $\mathrm{H} 7), 2.24-2.20$ (1H, m, H3), $2.12(1 \mathrm{H}, \mathrm{dt}, J=13.4$, $6.3 \mathrm{~Hz}, \mathrm{H} 3), 1.98$ (1H, dd, $J=16.0,7.5 \mathrm{~Hz}, \mathrm{H} 8), 1.80-1.69$ (1H, m, H8), $1.12\left(6 \mathrm{H}, \mathrm{t}, J=6.1 \mathrm{~Hz}, \mathrm{OCHMe}_{2}\right), 1.01(3 \mathrm{H}, \mathrm{d}, J=6.8$ $\mathrm{Hz}, \mathrm{C} 11), 0.95-0.90$ (6H, m, $\left.\mathrm{SiCH}_{2} \mathrm{Me}\right), 0.75-0.72(4 \mathrm{H}, \mathrm{m}$, $\left.\mathrm{SiCH}_{2} \mathrm{Me}\right) ;{ }^{13} \mathrm{C}$ NMR (125 MHz, $\left.\mathrm{CDCl}_{3}\right) \delta_{\mathrm{C}} 172.4,172.0,144.9$, 134.1, 127.8, 125.7, 65.2, 53.5, 52.7, 52.7, 36.4, 36.1, 29.5, 28.5, 25.8, 25.8, 25.2, 19.6, 7.0, 7.0, 5.7, 5.6; HRMS $\left(\mathrm{ES}^{+}\right)$calcd for $\mathrm{C}_{22} \mathrm{H}_{36} \mathrm{NaO}_{5} \mathrm{Si}[\mathrm{M}+\mathrm{Na}]^{+}$431.2224, found 431.2236. NMR data for 16a and 17a was obtained from a purified mixture of 16a and $17 \mathrm{a}(2.8: 1$ ratio).

Dimethyl (Z)-4-((E)-1-(diethyl(isopropoxy)silyl)but-2-en-1ylidene)-3-methylenecyclohexane-1,1-dicarboxylate (16a). ${ }^{1} \mathrm{H}$ NMR (500 MHz, $\left.\mathrm{CDCl}_{3}\right) \delta_{\mathrm{H}} 6.00(1 \mathrm{H}, \mathrm{dd}, J=15.5,1.5 \mathrm{~Hz}, \mathrm{H} 8)$, $5.32(1 \mathrm{H}, \mathrm{dq}, J=15.5,6.5 \mathrm{~Hz}, \mathrm{H} 9), 5.01(1 \mathrm{H}, \mathrm{d}, J=2.3 \mathrm{~Hz}$, H11), 4.87-4.83 (1H, m, H11), 4.00 (1H, sept, $J=6.0 \mathrm{~Hz}$, $\left.\mathrm{CHMe}_{2}\right), 3.72\left(6 \mathrm{H}, \mathrm{s}, \mathrm{CO}_{2} \mathrm{Me}\right), 2.81(2 \mathrm{H}, \mathrm{s}, \mathrm{H} 2), 2.58-2.52(2 \mathrm{H}$, m, H5), 2.11-2.06 (2H, m, H6), $1.74(3 \mathrm{H}, \mathrm{dd}, J=6.5,1.5 \mathrm{~Hz}$, H10), 1.13 (6H, d, $\left.J=6.0 \mathrm{~Hz}, \mathrm{CHMe}_{2}\right), 0.91(6 \mathrm{H}, \mathrm{t}, J=7.5 \mathrm{~Hz}$, $\mathrm{SiCH}_{2} \mathrm{Me}$ ), 0.69 (4H, $\left.=7.5 \mathrm{~Hz}, \mathrm{SiCH}_{2} \mathrm{Me}\right) ;{ }^{13} \mathrm{C} \mathrm{NMR}(126 \mathrm{MHz}$, $\left.\mathrm{CDCl}_{3}\right) \delta_{\mathrm{C}} 171.2,151.58,146.1,132.1,132.1,127.6,115.1,65.2$, 57.1, 52.8, 41.2, 32.3, 30.3, 25.9, 18.7, 7.3, 6.7.

Dimethyl (E)-3-(1-(diethyl(isopropoxy)silyl)buta-1,3-dien-1yl)-4-methylcyclopent-3-ene-1,1-dicarboxylate (17a). ${ }^{1} \mathrm{H}$ NMR $\left(500 \mathrm{MHz}, \mathrm{CDCl}_{3}\right) \delta_{\mathrm{H}} 6.36(1 \mathrm{H}, \mathrm{d}, J=10.6 \mathrm{~Hz}, \mathrm{H} 8), 6.31(1 \mathrm{H}$, ddd, $J=16.5,10.6,9.7 \mathrm{~Hz}, \mathrm{H} 9), 5.26$ (1H, dd, $J=16.5,2.0 \mathrm{~Hz}$, H10), 5.13 (1H, dd, $J=9.7,2.0, \mathrm{H} 10), 4.00$ (1H, sept, $J=6.0 \mathrm{~Hz}$, $\left.\mathrm{CHMe}_{2}\right), 3.73\left(6 \mathrm{H}, \mathrm{s}, \mathrm{CO}_{2} \mathrm{Me}\right), 2.61(1 \mathrm{H}, \mathrm{d}, J=17.2 \mathrm{~Hz}, \mathrm{H} 2)$, 2.45 (1H, d, $J=17.2 \mathrm{~Hz}, \mathrm{H} 2), 2.24-2.18$ (2H, m, H6 and H5), 2.14-2.11 (1H, m, H6), 1.87-1.82 (1H, m, H5), $1.50(3 \mathrm{H}, \mathrm{s}$, H11), $1.14\left(6 \mathrm{H}, \mathrm{d}, J=6.0 \mathrm{~Hz}, \mathrm{CHMe}_{2}\right), 0.91(6 \mathrm{H}, \mathrm{t}, J=7.5 \mathrm{~Hz}$, $\mathrm{SiCH}_{2} \mathrm{Me}$ ), $0.69\left(4 \mathrm{H}, J=7.5 \mathrm{~Hz}, \mathrm{SiCH}_{2} \mathrm{Me}\right) ;{ }^{13} \mathrm{C} \mathrm{NMR}(126 \mathrm{MHz}$, $\left.\mathrm{CDCl}_{3}\right) \delta_{\mathrm{C}} 172.4,172.2,144.5,140.2,134.4,130.5,123.2,118.9$, $65.2,53.9,52.7,52.7,36.3,28.3,27.7,26.0,25.9,20.3,7.0,6.8$, $5.5,5.3$.

Dimethyl 4-(diethyl(isopropoxy)silyl)-2-methyl-5,6,7,9-tetrahydro-1H-benzo[7]annulene-8,8(2H)-dicarboxylate (15g). Synthesised from 11c (51.4 $\mathrm{mg}, 0.111 \mathrm{mmol})$ and $(E)$-tributyl(prop-1-enyl)stannane 3a $(55.0 \mathrm{mg}, 0.166 \mathrm{mmol})$ using general procedure 3 . The crude product was purified by flash chromatography (5:1 pet. ether-ether) to afford $\mathbf{1 5} \mathbf{g}$ as a colourless oil (27.5 mg, $0.0651 \mathrm{mmol}, 58 \%$, mixture with 16b and 17b); $R_{\mathrm{f}}$ 0.52 (5:1 pet. ether-ether); IR (thin film) $\nu_{\max } / \mathrm{cm}^{-1} 2954$, 1736, 1455, 1228, 1172, 1007, 873, 729; ${ }^{1} \mathrm{H}$ NMR $(500 \mathrm{MHz}$, $\left.\mathrm{CDCl}_{3}\right) \delta_{\mathrm{H}} 5.98(1 \mathrm{H}, \mathrm{d}, J=3.2 \mathrm{~Hz}, \mathrm{H} 3), 3.95(1 \mathrm{H}$, septet, $J=$ $\left.5.9 \mathrm{~Hz}, \mathrm{CHMe}_{2}\right), 3.71\left(3 \mathrm{H}, \mathrm{s}, \mathrm{CO}_{2} \mathrm{Me}\right), 3.70\left(3 \mathrm{H}, \mathrm{s}, \mathrm{CO}_{2} \mathrm{Me}\right)$, 2.49-2.44 (2H, m, H9), 2.29-2.20 (2H, m, H5), 2.17-2.04 (3H, m, H5, H2, H1), 1.78-1.72 (1H, m, H1), 1.68-1.60 (2H, m, H7), 
1.38-1.33 (2H, m, H6), $1.13\left(3 \mathrm{H}, \mathrm{d}, J=6.0, \mathrm{CHMe}_{2}\right), 1.13(3 \mathrm{H}$, $\mathrm{d}, J=6.0, \mathrm{CHMe} 2), 0.99(3 \mathrm{H}, \mathrm{d}, J=7.0 \mathrm{~Hz}, \mathrm{CHMe}), 0.96-0.87$ $\left(6 \mathrm{H}, \mathrm{m}, \mathrm{SiCH}_{2} \mathrm{Me}\right), 0.76-0.60\left(4 \mathrm{H}, \mathrm{m}, \mathrm{SiCH}_{2} \mathrm{Me}\right) ;{ }^{13} \mathrm{C} \mathrm{NMR}$ $\left(125 \mathrm{MHz}, \mathrm{CDCl}_{3}\right) \delta_{\mathrm{C}} 172.3,172.0,145.3,137.8,135.6,129.2$, 65.1, 55.0, 52.3, 52.1, 39.7, 39.1, 37.2, 31.4, 29.8, 28.6, 26.7, 25.6, 25.4, 22.7, 19.4, 17.3, 13.6, 6.9, 6.8, 5.2, 5.1; HRMS $\left(\mathrm{ES}^{+}\right)$ calcd for $\mathrm{C}_{23} \mathrm{H}_{38} \mathrm{NaO}_{5} \mathrm{Si}[\mathrm{M}+\mathrm{Na}]^{+} 445.2381$, found 445.2386.

Dimethyl 8-(trimethylsilyl)bicyclo[5.2.0]nona-1,7-diene-3,3dicarboxylate (30). To $\mathrm{Pd}\left(\mathrm{PPh}_{3}\right)_{4}(5.0 \mathrm{mg}, 0.0045 \mathrm{mmol}, 5 \mathrm{~mol} \%)$ was added a degassed solution of bromoenyne $27^{8 a}(35.0 \mathrm{mg}$, $0.0899 \mathrm{mmol})$ and $\mathrm{Et}_{3} \mathrm{~N}(25.0 \mu \mathrm{l}, 0.180 \mathrm{mmol})$ in toluene $(1.2 \mathrm{~mL})$ under $\mathrm{Ar}$, and the mixture was refluxed in a preheated oil bath $\left(110^{\circ} \mathrm{C}\right)$ until completion of the reaction $(16 \mathrm{~h})$. The mixture was concentrated, and the residue purified by flash chromatography $\left(10: 1\right.$ pet. ether- $\left.\mathrm{Et}_{2} \mathrm{O}\right)$ to obtain 30 as a colourless oil (25.0 mg, $0.0811 \mathrm{mmol}, 90 \%) ; R_{\mathrm{f}} 0.46$ (2:1 pet. ether-Et ${ }_{2} \mathrm{O}$ ); IR (thin film) $\nu_{\max } / \mathrm{cm}^{-1} 2954,1736,1248,840$; ${ }^{1} \mathrm{H}$ NMR (500 MHz, MeOD) $\delta_{\mathrm{H}} 4.99(1 \mathrm{H}, \mathrm{s}, \mathrm{H} 2), 3.71(6 \mathrm{H}, \mathrm{s}$, $\left.\mathrm{CO}_{2} \mathrm{Me}\right), 2.73(2 \mathrm{H}, \mathrm{t}, J=2.9 \mathrm{~Hz}, \mathrm{H} 9), 2.38-2.32(2 \mathrm{H}, \mathrm{m}, \mathrm{H} 6)$, 2.29-2.25 (2H, m, H4), 1.67 (2H, app. qd, $J=6.0,4.5 \mathrm{~Hz}, \mathrm{H} 5)$, 0.12 (9H, s, SiMe); ${ }^{13} \mathrm{C}$ NMR (126 MHz, MeOD) $\delta_{\mathrm{C}} 173.1,159.9$, 150.9, 145.3, 110.9, 63.2, 53.3, 36.4, 35.7, 31.9, 23.6, -1.7; HRMS (ES+) calcd for $\mathrm{C}_{16} \mathrm{H}_{24} \mathrm{NaO}_{4} \mathrm{Si}[\mathrm{M}+\mathrm{Na}]^{+} 331.1336$, found 331.1340 .

Dimethyl 8-(diethyl(isopropoxy)- $\lambda^{4}$-sulfanyl)bicyclo[5.2.0]nona-1,7-diene-3,3-dicarboxylate (36). To $\mathrm{Pd}\left(\mathrm{PPh}_{3}\right)_{4}(5.0 \mathrm{mg}$, $0.0045 \mathrm{mmol}, 5 \mathrm{~mol} \%$ ) was added a degassed solution of bromoenyne 11c $(32.0 \mathrm{mg}, 0.0693 \mathrm{mmol})$ and $\mathrm{Et}_{3} \mathrm{~N}(20.0 \mu \mathrm{l}$, $0.144 \mathrm{mmol})$ in toluene $(1.2 \mathrm{~mL})$ under $\mathrm{Ar}$, and the mixture was heated in a preheated oil bath $\left(110^{\circ} \mathrm{C}\right)$ until completion of the reaction $(16 \mathrm{~h})$. The mixture was concentrated, and the residue was purified by flash chromatography $(10: 1$ pet. ether- $\left.\mathrm{Et}_{2} \mathrm{O}\right)$ to obtain 36 as a colourless oil $(23.0 \mathrm{mg}$, $0.0604 \mathrm{mmol}, 87 \%$ ); $R_{\mathrm{f}} 0.24$ (9:1 pet. ether-Et ${ }_{2} \mathrm{O}$ ); IR (thin film) $\nu_{\max } / \mathrm{cm}^{-1} 2955,1736,1565,1243,1031 ;{ }^{1} \mathrm{H}$ NMR $\left(500 \mathrm{MHz}, \mathrm{CDCl}_{3}\right) \delta_{\mathrm{H}} 5.09(1 \mathrm{H}, \mathrm{s}, \mathrm{H} 2), 3.99(1 \mathrm{H}$, sept, $J=6.0$ $\mathrm{Hz}, \mathrm{SiOCHMe}), 3.74\left(6 \mathrm{H}, \mathrm{s}, \mathrm{CO}_{2} \mathrm{Me}\right), 2.84(2 \mathrm{H}, \mathrm{t}, J=2.9 \mathrm{~Hz}$, H9), 2.39-2.35 (2H, m, H6), 2.33-2.30 (2H, m, H4), $1.71(2 \mathrm{H}$, dt, $J=10.8,5.6 \mathrm{~Hz}, \mathrm{H} 5), 1.15$ (6H, d, $J=6.0 \mathrm{~Hz}$, SiOCHMe), $0.96\left(6 \mathrm{H}, \mathrm{t}, J=7.9 \mathrm{~Hz}, \mathrm{SiCH}_{2} M e\right), 0.68(4 \mathrm{H}, \mathrm{q}, J=7.9 \mathrm{~Hz}$, $\left.\mathrm{SiCH}_{2} \mathrm{Me}\right) ;{ }^{13} \mathrm{C}$ NMR (101 MHz, $\left.\mathrm{CDCl}_{3}\right) \delta_{\mathrm{C}} 171.8,160.6,146.9$, 144.5, 110.5, 65.6, 62.0, 52.9, 36.9, 34.7, 31.5, 26.0, 22.6, 6.8, 5.7; HRMS $\left(\mathrm{ESI}^{+}\right.$) calcd for $\mathrm{C}_{20} \mathrm{H}_{32} \mathrm{NaO}_{5} \mathrm{Si}[\mathrm{M}+\mathrm{Na}]^{+}$403.1911, found 403.1916.

Dimethyl 6-methyl-4-oxo-4,5,6,7-tetrahydro- $1 \mathrm{H}$-indene-2,2(3H)-dicarboxylate (37). 15a (16.8 mg, $0.0458 \mathrm{mmol})$ was dissolved in THF-MeOH $(1: 1,400 \mu \mathrm{L})$. KF $(5.3 \mathrm{mg}, 0.090 \mathrm{mmol})$, $\mathrm{KHCO}_{3}(9.2 \mathrm{mg}, 0.090 \mathrm{mmol}), \mathrm{H}_{2} \mathrm{O}_{2}(30 \%$ aq., $5.2 \mu \mathrm{L}$, $0.050 \mathrm{mmol}$ ) were added and the reaction mixture was heated to $40{ }^{\circ} \mathrm{C}$ for $3 \mathrm{~h}$. The reaction was allowed to cool to $\mathrm{rt}$, then it was diluted with $\mathrm{CH}_{2} \mathrm{Cl}_{2}$ and water. The organic extract was washed with water, dried $\left(\mathrm{MgSO}_{4}\right)$, and concentrated. The product was purified by flash chromatography $(2: 1$ pet. etherether) to afford 37 as a colourless oil $(5.3 \mathrm{mg}, 0.020 \mathrm{mmol}$, $43 \%) ; R_{\mathrm{f}} 0.21$ (2:1 pet. ether-ether); IR (thin film) $\nu_{\max } / \mathrm{cm}^{-1}$ 2349, 1734, 1667, 1434, 1262, 913, 745; ${ }^{1} \mathrm{H}$ NMR (400 MHz,
$\left.\mathrm{CDCl}_{3}\right) \delta_{\mathrm{H}} 3.75\left(6 \mathrm{H}, \mathrm{s}, \mathrm{CO}_{2} \mathrm{Me}\right), 3.23-3.21(4 \mathrm{H}, \mathrm{m}, \mathrm{H} 1, \mathrm{H} 3), 2.42$ $(1 \mathrm{H}, \mathrm{dd}, J=17.0,3.9 \mathrm{~Hz}, \mathrm{H} 5), 2.42-2.36$ (1H, m, H7), 2.32-2.20 (1H, m, H6), 2.09 (1H, dd, $J=17.0,12.0 \mathrm{~Hz}, \mathrm{H} 5), 2.07-2.00$ (1H, m, H7), 1.07 (3H, d, $J=6.5 \mathrm{~Hz}, M e) ;{ }^{13} \mathrm{C}$ NMR $(125 \mathrm{MHz}$, $\left.\mathrm{CDCl}_{3}\right) \delta_{\mathrm{C}} 194.9,172.0$ (2C), 158.7, 134.8, 57.8, 52.5 (2C), 45.8, 45.2, 38.6, 33.8, 31.0, 21.0; HRMS $\left(\mathrm{ES}^{+}\right)$calcd for $\mathrm{C}_{14} \mathrm{H}_{19} \mathrm{O}_{5}$ $[\mathrm{M}+\mathrm{H}]^{+}$267.1227, found 267.1225.

Dimethyl 4-(diethyl(isopropoxy)silyl)-6-phenyl-1H-indene2,2(3H)-dicarboxylate (38). To a solution of 15c $(20.0 \mathrm{mg}$, $0.0438 \mathrm{mmol})$ in $\mathrm{CH}_{2} \mathrm{Cl}_{2}(1 \mathrm{~mL})$ was added $\mathrm{MnO}_{2}(19.0 \mathrm{mg}$, $0.220 \mathrm{mmol}$ ) and the reaction mixture was stirred at $30{ }^{\circ} \mathrm{C}$ for $12 \mathrm{~h}$. The mixture was filtered through a pad of Celite and concentrated, and the residue was purified by flash chromatography (5:1 pet. ether-ether) to afford 38 as a colourless oil (17.0 mg, $0.0374 \mathrm{mmol}, 85 \%$ ); $R_{\mathrm{f}} 0.31$ (5:1 pet. ether-ether); IR (thin film) $\nu_{\max } / \mathrm{cm}^{-1} 2923,2853,1740,1460,699 ;{ }^{1} \mathrm{H}$ NMR $\left(500 \mathrm{MHz}, \mathrm{CDCl}_{3}\right) \delta_{\mathrm{H}} 7.60-7.40(6 \mathrm{H}, \mathrm{m}, \mathrm{H} 5, \mathrm{H} 7, \mathrm{ArH}), 7.33(1 \mathrm{H}$, $\mathrm{t}, J=7.3 \mathrm{~Hz}, \mathrm{ArH}), 4.08\left(1 \mathrm{H}\right.$, septet, $\left.J=6.1 \mathrm{~Hz}, \mathrm{CHMe} \mathrm{M}_{2}\right), 3.76$ $\left(6 \mathrm{H}, \mathrm{s}, \mathrm{CO}_{2} \mathrm{Me}\right), 3.74(2 \mathrm{H}, \mathrm{s}, \mathrm{H} 1$ or $\mathrm{H} 3), 3.63(2 \mathrm{H}, \mathrm{s}, \mathrm{H} 1 \mathrm{or} \mathrm{H} 3)$, $1.19\left(6 \mathrm{H}, \mathrm{d}, J=6.1 \mathrm{~Hz}, \mathrm{CHMe} e_{2}\right), 1.03-0.93\left(4 \mathrm{H}, \mathrm{m}, \mathrm{SiCH}_{2} \mathrm{Me}\right)$; ${ }^{13} \mathrm{C}$ NMR $\left(125 \mathrm{MHz}, \mathrm{CDCl}_{3}\right) \delta_{\mathrm{C}} 172.2,144.6,141.5,139.9$, 139.4, 132.7, 132.5, 128.7, 127.1, 127.0, 124.3, 65.5, 60.4, 52.9, 41.4, 40.1, 25.8, 6.8, 5.5; HRMS $\left(\mathrm{ES}^{+}\right)$calcd for $\mathrm{C}_{26} \mathrm{H}_{34} \mathrm{NaO}_{5} \mathrm{Si}$ $[\mathrm{M}+\mathrm{Na}]^{+} 477.2068$, found 477.2053 .

4-(Diethyl(isopropoxy)silyl)-6-methyl-2-tosylisoindoline (39). To a solution of $\mathbf{1 5 d}(29.0 \mathrm{mg}, 0.0669 \mathrm{mmol})$ in $\mathrm{CH}_{2} \mathrm{Cl}_{2}(1 \mathrm{~mL})$ was added $\mathrm{MnO}_{2}(50.0 \mathrm{mg}, 0.460 \mathrm{mmol})$ and the reaction mixture was stirred at $30{ }^{\circ} \mathrm{C}$ for $12 \mathrm{~h}$. The mixture was filtered through a pad of Celite and concentrated, and the residue was purified by flash chromatography ( $5: 1$ pet. ether-ether) to afford 39 as a colourless oil $(27.0 \mathrm{mg}, 0.0625 \mathrm{mmol}, 93 \%) ; R_{\mathrm{f}}$ 0.30 (5:1 pet. ether-ether); IR (thin film) $\nu_{\max } / \mathrm{cm}^{-1} 2958$, 1733, 1596, 1433, 1259, 699; ${ }^{1} \mathrm{H}$ NMR (500 $\left.\mathrm{MHz}, \mathrm{CDCl}_{3}\right) \delta_{\mathrm{H}}$ $7.76(2 \mathrm{H}, \mathrm{d}, J=8.3 \mathrm{~Hz}, \operatorname{ArH}), 7.29(2 \mathrm{H}, \mathrm{d}, J=8.3 \mathrm{~Hz}, \operatorname{ArH}), 7.14$ (1H, s, H5), 6.99 (1H, s, H7), 4.67 (2H, s, H3), 4.56 (2H, s, H1), $4.05\left(1 \mathrm{H}\right.$, sept, $\left.J=6.3 \mathrm{~Hz}, \mathrm{CHMe} \mathrm{M}_{2}\right), 2.40(3 \mathrm{H}, \mathrm{s}, \mathrm{Ts}-\mathrm{Me}), 2.31$ $(3 \mathrm{H}, \mathrm{s}, \mathrm{Me}), 1.18\left(6 \mathrm{H}, \mathrm{d}, J=6.3 \mathrm{~Hz}, \mathrm{CHMe} e_{2}\right), 0.92(6 \mathrm{H}, \mathrm{t}, J=$ $\left.6.8 \mathrm{~Hz}, \mathrm{SiCH}_{2} \mathrm{Me}\right), 0.88-0.82\left(4 \mathrm{H}, \mathrm{m}, \mathrm{SiCH}_{2} \mathrm{Me}\right) ;{ }^{13} \mathrm{C} \mathrm{NMR}$ $\left(125 \mathrm{MHz}, \mathrm{CDCl}_{3}\right) \delta_{\mathrm{C}} 143.4,138.8,136.3,135.6,134.4,133.7$, 131.1, 129.7, 127.6, 124.2, 65.4, 54.6, 53.3, 25.7, 21.4, 21.2, 6.8, 5.5; HRMS $\left(\mathrm{ES}^{+}\right)$calcd for $\mathrm{C}_{23} \mathrm{H}_{33} \mathrm{NNaO}_{3} \mathrm{SSi}[\mathrm{M}+\mathrm{Na}]^{+}$ 454.1843, found 454.1845.

Dimethyl 4-hydroxy-6-phenyl-1H-indene-2,2(3H)-dicarboxylate (40). To a solution of $38(17.0 \mathrm{mg}, 0.0374 \mathrm{mmol})$ in THF$\mathrm{MeOH}(1: 1,1 \mathrm{~mL})$ was added and TBAF (1 M solution in THF, $13.0 \mu \mathrm{L}, 0.013 \mathrm{mmol}), \mathrm{KHCO}_{3}(7.5 \mathrm{mg}, 0.080 \mathrm{mmol})$ and $\mathrm{H}_{2} \mathrm{O}_{2}$ (30\% aq., $13 \mu \mathrm{L}, 0.12 \mathrm{mmol}$ ). The reaction mixture was heated to $60{ }^{\circ} \mathrm{C}$ for $3 \mathrm{~h}$, then it was cooled to rt, diluted with $\mathrm{CH}_{2} \mathrm{Cl}_{2}$ and water. The organic phase was washed with water, dried $\left(\mathrm{MgSO}_{4}\right)$, and concentrated. The residue was purified by flash chromatography ( $2: 1$ pet. ether-ether) to afford 40 (9.4 mg, $0.0288 \mathrm{mmol}, 78 \%$ ); $R_{\mathrm{f}} 0.15$ (2:1 pet. ether-ether); IR (thin film) $\nu_{\max } / \mathrm{cm}^{-1} 2954,1733,1596,1434,1260,1165,864$, 699; ${ }^{1} \mathrm{H}$ NMR (500 MHz, $\mathrm{CDCl}_{3}$ ) $\delta_{\mathrm{H}} 7.52(2 \mathrm{H}, \mathrm{d}, J=7.5 \mathrm{~Hz}, \mathrm{ArH})$, $7.41(2 \mathrm{H}, \mathrm{t}, J=7.5 \mathrm{~Hz}, \operatorname{ArH}), 7.32(1 \mathrm{H}, \mathrm{t}, J=7.5 \mathrm{~Hz}, \mathrm{ArH}), 7.01$ $(1 \mathrm{H}, \mathrm{s}, \mathrm{H} 7), 6.85$ (1H, s, H5), $3.78\left(6 \mathrm{H}, \mathrm{s}, \mathrm{CO}_{2} \mathrm{Me}\right), 3.66(2 \mathrm{H}, \mathrm{s}$, 
H1), 3.60 (2H, s, H3); ${ }^{13} \mathrm{C}$ NMR $\left(125 \mathrm{MHz}, \mathrm{CDCl}_{3}\right) \delta_{\mathrm{C}} 172.0$, $151.8,142.8,142.5,140.9$, 128.7, 127.2, 127.1, 124.7, 115.6, 112.6, 60.3, 53.0, 40.9, 36.8; HRMS (ES ${ }^{-}$) calcd for $\mathrm{C}_{19} \mathrm{H}_{17} \mathrm{O}_{5}$ $[\mathrm{M}]^{-}$325.1081, found 325.1081.

6-Methyl-2-tosylisoindolin-4-ol (41). To a solution of 39 (20.0 mg, $0.0463 \mathrm{mmol}$ ) in THF-MeOH (1:1, $1 \mathrm{~mL}$ ) was added and TBAF ( $1 \mathrm{M}$ solution in THF, $16.0 \mu \mathrm{L}, 0.016 \mathrm{mmol}$ ), $\mathrm{KHCO}_{3}$ (9.0 mg, $0.10 \mathrm{mmol}$ ) and $\mathrm{H}_{2} \mathrm{O}_{2}(30 \%$ aq., $17 \mu \mathrm{L}, 0.15 \mathrm{mmol}$ ). The reaction mixture was heated to $60{ }^{\circ} \mathrm{C}$ for $3 \mathrm{~h}$, then it was cooled to rt, diluted with $\mathrm{CH}_{2} \mathrm{Cl}_{2}$ and water. The organic phase was washed with water, dried $\left(\mathrm{MgSO}_{4}\right)$, and concentrated. The residue was purified by flash chromatography $(2: 1$ pet. etherether) to afford 41 as a colourless oil $(14.0 \mathrm{mg}, 0.0461 \mathrm{mmol}$, $99 \%$ ); $R_{\mathrm{f}} 0.26$ (2:1 pet. ether-ether); IR (thin film) $\nu_{\max } / \mathrm{cm}^{-1}$ 2954, 1733, 1596, 1434, 1260, 1165, 864, 699; ${ }^{1} \mathrm{H}$ NMR $\left(500 \mathrm{MHz}, \mathrm{CDCl}_{3}\right) \delta_{\mathrm{H}} 7.76(2 \mathrm{H}, \mathrm{d}, J=7.7 \mathrm{~Hz}, \mathrm{ArH}), 7.31(2 \mathrm{H}, \mathrm{d}$, $J=7.7 \mathrm{~Hz}, \mathrm{ArH}), 6.54$ (1H, s, H7), 6.47 (1H, s, H5), 4.57 (4H, s, $\mathrm{H} 1, \mathrm{H} 3), 2.40(3 \mathrm{H}, \mathrm{s}, \mathrm{TsMe}), 2.24(3 \mathrm{H}, \mathrm{s}, \mathrm{Me}) ;{ }^{13} \mathrm{C} \mathrm{NMR}$ $\left(125 \mathrm{MHz}, \mathrm{CDCl}_{3}\right) \delta_{\mathrm{C}} 150.6,143.6,139.8,138.2,133.6,129.8$, 127.6, 119.7, 115.2, 114.8, 54.0, 51.4, 21.5, 21.2; HRMS $\left(\mathrm{ES}^{+}\right)$ calcd for $\mathrm{C}_{16} \mathrm{H}_{17} \mathrm{NNaO}_{3} \mathrm{~S}[\mathrm{M}+\mathrm{Na}]^{+} 326.0821$, found 326.0824 .

\section{Acknowledgements}

We thank the EPSRC (Advanced Research Fellowship to E.A.A.; EP/E055273/1, studentship to M.-C.A.C.), the German Academic Exchange Service (DAAD) for a postdoctoral fellowship (B.G.), and A*STAR for a National Science Scholarship (S.S.G.).

\section{Notes and references}

1 (a) J. H. P. Tyman, Synthetic and Natural Phenols, Elsevier, New York, 1996; (b) Z. Rappoport, The Chemistry of Phenols, Wiley-VCH, Weinheim, 2003; (c) I. P. Singh, S. B. Bharate and K. K. Bhutani, Curr. Sci., 2005, 89, 269-290.

2 (a) For examples of tetracycline and pyranonaphthoquinone natural products, see: A. G. Myers, D. A. Kummer, D. R. Li and A. Dion, Chem. Sci., 2011, 2, 1710-1718; (b) A. G. Myers, C. X. Sun, Q. Wang, J. D. Brubaker, P. M. Wright, C. D. Lerner, K. Noson, M. Charest, D. R. Siegel and Y. M. Wang, J. Am. Chem. Soc., 2008, 130, 17913-17927; (c) G. Minotti, P. Menna, E. Salvatorelli, G. Cairo and L. Gianni, Pharmacol. Rev., 2004, 56, 185-229; (d) J. Sperry, P. Bachu and M. A. Brimble, Nat. Prod. Rep., 2008, 25, 376-400.

3 For examples, see ref. $1 a$ and: P. Hanson, J. R. Jones, A. B. Taylor, P. H. Walton and A. W. Timms, J. Chem. Soc., Perkin Trans. 2, 2002, 1135-1150.

4 (a) For reviews of $\mathrm{C}-\mathrm{X}$ phenolation, see: M. C. Willis, Angew. Chem., Int. Ed., 2007, 46, 3402-3404; (b) S. Enthaler and A. Company, Chem. Soc. Rev., 2011, 40, 4912-4924; (c) For reviews of $\mathrm{C}-\mathrm{H}$ phenolation, see: D. A. Alonso, C. Najera, I. M. Pastor and M. Yus, Chem. - Eur. J., 2010,
16, 5274-5284; (d) M. S. Sanford and T. W. Lyons, Chem. Rev., 2010, 110, 1147-1169.

5 (a) The equivalent oxidation of arylboranes can also provide phenols, but in most cases these derivative are less amenable to processing through multistep synthesis. See: R. E. Maleczka, F. Shi, D. Holmes and M. R. Smith, J. Am. Chem. Soc., 2003, 125, 7792-7793; (b) G. A. Molander and L. N. Cavalcanti, J. Org. Chem., 2011, 76, 623-630; (c) X. Y. Wang, J. M. Xu, C. W. Shao, D. Y. Su, G. L. Cheng and Y. F. Hu, Org. Lett., 2010, 12, 1964-1967.

6 (a) S. Bracegirdle and E. A. Anderson, Chem. Commun., 2010, 46, 3454-3456; (b) E. J. Rayment, N. Summerhill and E. A. Anderson, J. Org. Chem., 2012, 77, 7052-7060.

7 (a) For other examples of arylsilane oxidation, see: J. F. Hartwig and E. M. Simmons, J. Am. Chem. Soc., 2010, 132, 17092-17095; (b) M. Suginome and H. Ihara, J. Am. Chem. Soc., 2009, 131, 7502-7503; (c) J. D. Sunderhaus, H. Lam and G. B. Dudley, Org. Lett., 2003, 5, 4571-4573; (d) K. Tamao, Proc. Jpn. Acad. B, Phys. Biol. Sci., 2008, 84, 123-133; (e) K. Tamao, T. Kakui, M. Akita, T. Iwahara, R. Kanatani, J. Yoshida and M. Kumada, Tetrahedron, 1983, 39, 983-990; $(f)$ For a borodesilylation/oxidation sequence, see: V. Gevorgyan, C. H. Huang, N. Chernyak and A. S. Dudnik, Adv. Synth. Catal., 2011, 353, 12851305.

8 (a) S. B. J. Kan and E. A. Anderson, Org. Lett., 2008, 10, 2323-2326; (b) M.-C. A. Cordonnier, S. B. J. Kan and E. A. Anderson, Chem. Commun., 2008, 5818-5820.

9 (a) J. Suffert, B. Salem and P. Klotz, J. Am. Chem. Soc., 2001, 123, 12107-12108; (b) B. Salem, P. Klotz and J. Suffert, Org. Lett., 2003, 5, 845-848; (c) B. Salem, E. Delort, P. Klotz and J. Suffert, Org. Lett., 2003, 5, 2307-2310; (d) B. Salem and J. Suffert, Angew. Chem., Int. Ed., 2004, 43, 2826-2830; (e) C. Bour, G. Blond, B. Salem and J. Suffert, Tetrahedron, 2006, 62, 10567-10581; (f) For the most recent publication on this topic, and leading references, see: M. Charpenay, A. Boudhat, C. Hulot, G. Blond and J. Suffert, Tetrahedron, 2013, 69, 7568-7591; $(g)$ For seminal work on alkyne carbopalladation followed by Stille cross-coupling, see: B. Burns, R. Grigg, P. Ratananukul, V. Sridharan, P. Stevenson, S. Sukirthalingam and T. Worakun, Tetrahedron Lett., 1988, 29, 5565-5568; $(h)$ E. Negishi, Y. Noda, F. Lamaty and E. J. Vawter, Tetrahedron Lett., 1990, 31, 4393-4396; (i) J. M. Nuss, M. M. Murphy, R. A. Rennels, M. M. Heravi and B. J. Mohr, Tetrahedron Lett., 1993, 34, 3079-3082; (j) P. Fretwell, R. Grigg, J. M. Sansano, V. Sridharan, S. Sukirthalingam, D. Wilson and J. Redpath, Tetrahedron, 2000, 56, 7525-7539; ( $k$ ) For a review of palladium-catalyzed cascade cyclizations, see: T. Vlaar, E. Ruijter and R. V. A. Orru, Adv. Synth. Catal., 2011, 353, 809-841; (l) For a general review of carbopalladation chemistry, see: E. Negishi, C. Coperet, S. Ma, S. Y. Liou and F. Liu, Chem. Rev., 1996, 96, 365-394.

10 Suffert has also noted the utility of silylalkynes in similar cascades. See: G. Blond, C. Bour, B. Salem and J. Suffert, Org. Lett., 2008, 10, 1075-1078. 
11 (a) For recent reviews and leading references, see: Y. Nakao and T. Hiyama, Chem. Soc. Rev., 2011, 40, 4893-4901; (b) S. E. Denmark and J. H. C. Liu, Angew. Chem., Int. Ed., 2010, 49, 2978-2986.

12 S. S. Goh, H. Baars, B. Gockel and E. A. Anderson, Org. Lett., 2012, 14, 6278-6281.

13 (a) For other de novo routes to fused-ring phenols, see: A. S. K. Hashmi, T. Haffner, M. Rudolph and F. Rominger, Chem. - Eur. J., 2011, 17, 8195-8201; (b) A. S. K. Hashmi, M. Rudolph, J. W. Bats, W. Frey, F. Rominger and T. Oeser, Chem. - Eur. J., 2008, 14, 6672-6678; (c) A. S. K. Hashmi, R. Salathe and W. Frey, Chem. - Eur. J., 2006, 12, 69916996; (d) K. Hashmi, A. Stephen, T. M. Frost and J. W. Bats, J. Am. Chem. Soc., 2000, 122, 11553-11554; (e) K. Tanaka, H. Hara and M. Hirano, Org. Lett., 2009, 11, 1337-1340; (f) S. Akai, T. Ikawa, S. I. Takayanagi, Y. Morikawa, S. Mohri, M. Tsubakiyama, M. Egi, Y. Wada and Y. Kita, Angew. Chem., Int. Ed., 2008, 47, 7673-7676; (g) K. Yoshida, R. Narui and T. Imamoto, Chem. - Eur. J., 2008, 14, 97069713.

14 L. H. Li, D. Wang and T. H. Chan, Organometallics, 1994, 13, 1757-1761.

15 (a) Diethylaminochlorodiethylsilane was prepared according to the procedure of Tamao: K. Tamao, A. Kawachi and Y. Ito, Organometallics, 1993, 12, 580-582; (b) For an alternative preparation, see: J. Beignet, P. J. Jervis and L. R. Cox, J. Org. Chem., 2008, 73, 5462-5475.

16 (a) R. L. Miller, S. V. Maifeld and D. Lee, Org. Lett., 2004, 6, 2773-2776; (b) S. Chang, M. Lee and S. Ko, J. Am. Chem. Soc., 2000, 122, 12011-12012.

17 See the ESI $\dagger$ for NMR spectra of a purified mixture containing predominantly $16 \mathbf{a}$ and $17 \mathbf{a}$.

18 (a) C. Amatore, S. Bensalem, S. Ghalem and A. Jutand, J. Organomet. Chem., 2004, 689, 4642-4646; (b) B. H. Lipshutz and A. Krasovskiy, Org. Lett., 2011, 13, 3818-3821.

19 M. Murakami, K. Itami and Y. Ito, J. Am. Chem. Soc., 1997, 119, 7163-7164.
20 A reductive elimination to the syn-triene followed by rapid electrocyclization cannot be ruled out; however, we have never observed such intermediates.

21 J. Q. Yu, M. J. Gaunt and J. B. Spencer, J. Org. Chem., 2002, 67, 4627-4629.

22 X. Wang, H. Chakrapani, J. W. Madine, M. A. Keyerleber and R. A. Widenhoefer, J. Org. Chem., 2002, 67, 27782788.

23 An intermediate of this type has also been proposed in the mechanistically distinct palladium(II)-catalyzed cyclization of an allenynoate to give a fused cyclobutene. See: C. H. Oh, D. I. Park, S. H. Jung, V. R. Reddy, A. K. Gupta and Y. M. Kim, Synlett, 2005, 2092-2094.

24 (a) A. Furstner, A. Schlecker and C. W. Lehmann, Chem. Commun., 2007, 4277-4279; (b) N. Saito, Y. Tanaka and Y. Sato, Org. Lett., 2009, 11, 4124-4126.

25 (a) For a Mo-catalyzed route, see: Q. Shen and G. B. Hammond, J. Am. Chem. Soc., 2002, 124, 6534-6535; (b) For examples of syntheses via thermal $[2+2]$ cycloaddition, see: K. M. Brummond and D. T. Chen, Org. Lett., 2005, 7, 3473-3475; (c) H. Ohno, T. Mizutani, Y. Kadoh, A. Aso, K. Miyamura, N. Fujii and T. Tanaka, J. Org. Chem., 2007, 72, 4378-4389; (d) C. Mukai, Y. Hara, Y. Miyashita and F. Inagaki, J. Org. Chem., 2007, 72, 4454-4461.

26 K. Tamao, M. Kumada and K. Maeda, Tetrahedron Lett., 1984, 25, 321-324.

27 R. L. Greenaway, C. D. Campbell, O. T. Holton, C. A. Russell and E. A. Anderson, Chem. - Eur. J., 2011, 17, 14366-14370.

28 We found it possible to use a sub-stoichiometric quantity of TBAF to effect these oxidations. See ref. $6 b$.

29 M. G. Organ, J. T. Cooper, L. R. Rogers, F. Soleymanzadeh and T. Paul, J. Org. Chem., 2000, 65, 7959-7970.

30 F. Hoffmann, J. Wagler and G. Roewer, Eur. J. Inorg. Chem., 2010, 1133-1142.

31 P. J. Parsons, P. Willis and S. C. Eyley, Tetrahedron, 1992, 48, 9461-9472. 